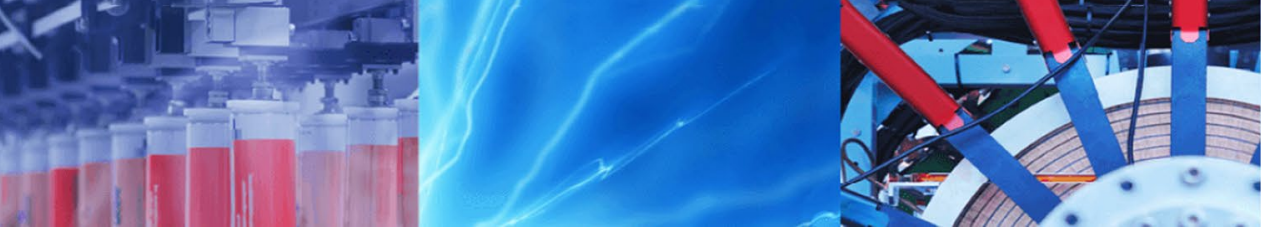

Research Article

\title{
Gravity study of the Douala sub-basin (Cameroon) using Euler 3D deconvolution, source edge detection (SED) and special function analysis
}

\author{
Eric N. Ndikum ${ }^{1,2,4}$ (I) F. Koumetio ${ }^{3} \cdot$ Victor J. Kenfack ${ }^{6} \cdot$ Charles T. Tabod $^{1,5}$
}

(c) Springer Nature Switzerland AG 2019

\begin{abstract}
Gravity data over an extending section of the north west portion of the Douala sedimentary sub-basin have been processed for both shallow and deep geologic contacts. Qualitative analysis, Euler 3D deconvolution, source edge detection (SED) and analysis of some special functions (horizontal gradient magnitude, analytic signal and the local wavenumber) have been carried out. One major peak and two minor peaks were highlighted on the anomaly maps as well as three major zones of anomaly which move from a very high positive anomaly zone in the center through an average positive zone to an average negative zone. Results of Euler 3D deconvolution and SED emphasized the presence of the underlying intrusive body to depths greater than $4 \mathrm{~km}$ in this study area and also suggested other geologic contacts above it. Solutions of special function analysis indicated that these geological contacts consist of some major faults with $\mathrm{N}-\mathrm{S}$, NE-SW, NW-SE and E-W orientations as well as some minor faults with NW-SE, E-W and NE-SW orientations having dip directions generally pointing away from the center of the study area. The faults and contacts were shown to be buried at a minimum depth of about $2 \mathrm{~km}$ with the majority having a structural index value in the range -0.8 to 0 .
\end{abstract}

Keywords Bouguer anomaly · Euler 3D · Edge detection · Special function analysis · Geologic contacts

\section{Introduction}

The Douala sedimentary sub-basin which constitutes the upper section of the Douala-Kribi/Campo sedimentary basin is one of the main basins of the Cameroon Atlantic basin located in the Gulf of Guinea. This sub-basin, unlike the adjacent Kribi/Campo sub-basin which has been subject to a number of geophysical studies [1-12], has in recent times recorded a few number of geophysical studies like those of [13-15]. Using audio magnetotellurics soundings, [12] were able to highlight two blocks with different morphologies on the basement-sedimentary transition zone around the eastern margin of the Douala basin and they as well estimated the total sedimentary thickness at $1.1 \mathrm{~km}$. Aeromagnetic data from the Douala sedimentary basin were processed through the analysis of the maxima of the horizontal gradient and of the analytic signal as well as Euler's deconvolution by [15] to explain the faulting system responsible for fracturing of the basin basement. Results of this study showed that the major fracturing directions are oriented NW-SE and NE-SW and the main faults are located at depths of up to $2 \mathrm{~km}$.

Nevertheless, a lot of studies related to oil and natural gas prospection have been carried out by scientist and petroleum industries which have led to the characterization and stratigraphy of the sub-basin. These works for the

$\triangle$ Eric N. Ndikum, ndikumeric@yahoo.com | ${ }^{1}$ Department of Physics, University of Yaoundé 1, Yaoundé, Cameroon. ${ }^{2}$ Department of Fundamental Sciences, Higher Technical Teacher Training College (HTTTC) Bambili, The University of Bamenda, Bamenda, Cameroon. ${ }^{3}$ Department of Physics, Faculty of Science, University of Dschang, PO Box 67, Dschang, Cameroon. ${ }^{4}$ Department of Physics, HTTC Bambili, The University of Bamenda, Bamenda, Cameroon. ${ }^{5}$ Department of Physics, Faculty of Science, The University of Bamenda, Bamenda, Cameroon. ${ }^{6}$ Department of Earth Science, Faculty of Science, University of Dschang, PO Box 67, Dschang, Cameroon. 
greater part were quite globalizing ignoring specificities of parts of the basin. Considering the confidential nature of such studies, many of the results are unpublished [16, 17]. Taking into consideration the important economic potentials of the Douala sedimentary sub-basin as well as the need to highlight the geophysical understanding of its subsurface, this study shall process gravity data using 3D Euler and source edge detection (SED) techniques as well as the analysis of some special functions to further characterize the depths and alignment of geological features beneath this basin.

\section{Geologic and tectonic settings}

Bounded geographically between latitudes $3^{\circ} 03^{\prime} \mathrm{N}$ and $4^{\circ} 06^{\prime} \mathrm{N}$ and longitudes $9^{\circ} 00^{\prime}$ and $10^{\circ} 00^{\prime} \mathrm{E}$ (Fig. 1), the Douala sedimentary sub-basin covers a total surface area of $12,805 \mathrm{~km}^{2}$, where about $6955 \mathrm{~km}^{2}$ is on land and about $5850 \mathrm{~km}^{2}$ is offshore [16]. Its regional stratigraphy and

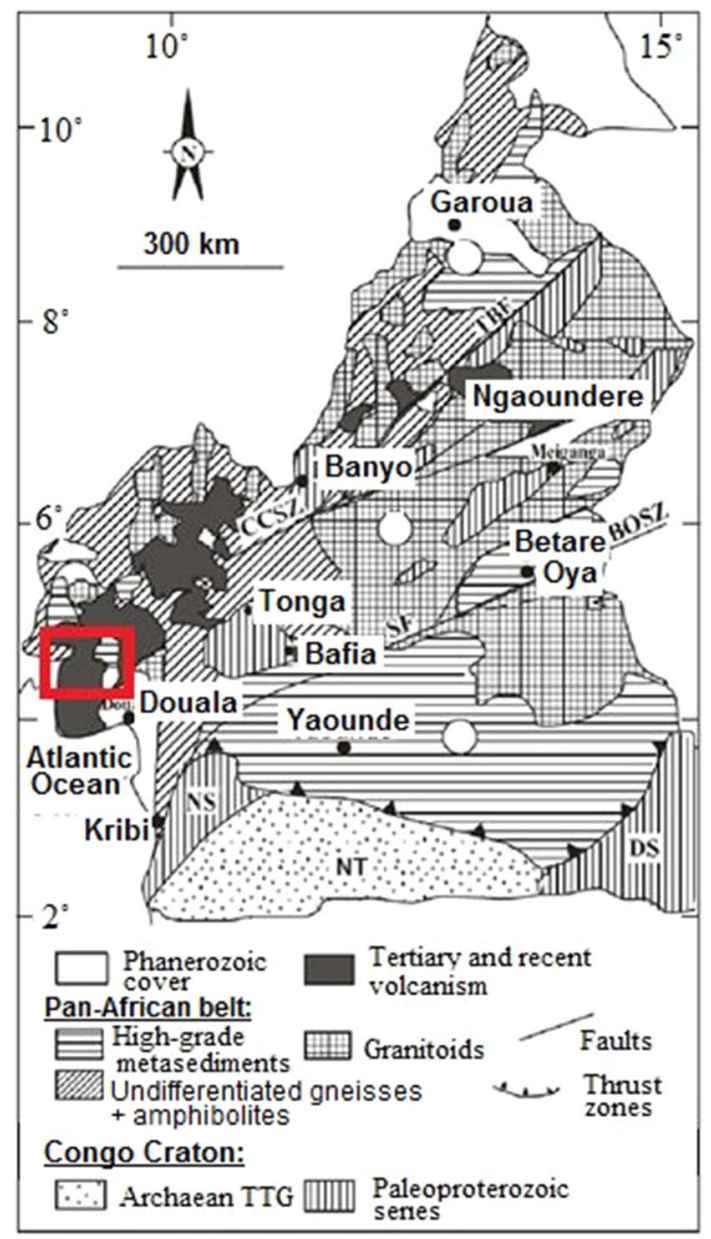

Fig. 1 Location map of Cameroon (West Africa) with red rectangular box indicating the study area. Modified from [33] tectonics are summarized by four main phases of evolution related to the pre-, syn- and post-rift separation of Africa from South America [17]. To the north west of the Douala basin is located Mount Cameroon, while to its east and west margins are the Precambrian basement and the Gulf of Guinea, respectively. Pauken [18] suggested a maximum thickness of 8-10 km for the sedimentary section of the Douala basin. The Douala basin which is part of the Cameroonian coastal basin alongside the Kribi/Campo basin and the Rio del Rey (or Bamusso) basin is part of the West African margin formed during the gradual widening of the South Atlantic by the South-North continental tear [19]. Great similarities exist between the history of the Douala basin and those of all the basins of the West African margin [20-23]. Basins of the West African coast from Angola to Cameroon suggest that there exist links between their tectonic evolution and sedimentary sequences [24, 25].

The syn-rift phase (Apto-Albian), the transition phase (Albian-Cenomanian) and the expansion and marginal oceanic accretion phase (Cenomanian to present) are three main phases which summarize the geodynamic context of the Douala sub-basin [26, 27]. These phases have been confirmed to exist by Manga [28]. The lithostratigraphy of the Douala basin is made up of seven major formations related to its geodynamic and sedimentary evolution [29-32]. These formations include: the Mundeck formation (Cenomanian-Campanian), the Logbadjeck formation (Cenomanian-Campanian), the Logbaba formation (Maastrichtian), the N'kapa formation (Paleocene-Eocene), the Souellaba formation (Oligocene), the Matanda formation (Miocene) and the Wouri formation (Plio-Pleistocene). Of all these formations, only the Mundeck formation is part of the syn-rift period while the rest of the formations are of the post-rift sequence.

\section{Methodology}

\subsection{Data}

The gravity data used in this study were first acquired between 1963 and 1968, during a detailed gravity survey of Cameroon and Central Africa undertaken by the Office de la Recherche Scientifique et Technique d'Outre-Mer (ORSTOM) [34, 35], and later on between 1970 and 1990 through other geophysical (gravity) campaigns [36-39]. The survey yielded data points with irregular inter-station distances of the order of 4 to $5 \mathrm{~km}$ as a result of the difficulties in accessing the area, which belongs to the tropical rain forest. Variations in the gravity field were measured using the Worden gravimeters (No. 313, 600, 69 and 135) and the Lacoste \& Romberg (model G, Nos. 471 and 828). These data constitute simple Bouguer anomaly values 
Fig. 2 Bouguer anomaly map of the NW portion of the Douala sedimentary sub-basin. The white dots represent approximately the boundary between the continent and the Atlantic Ocean

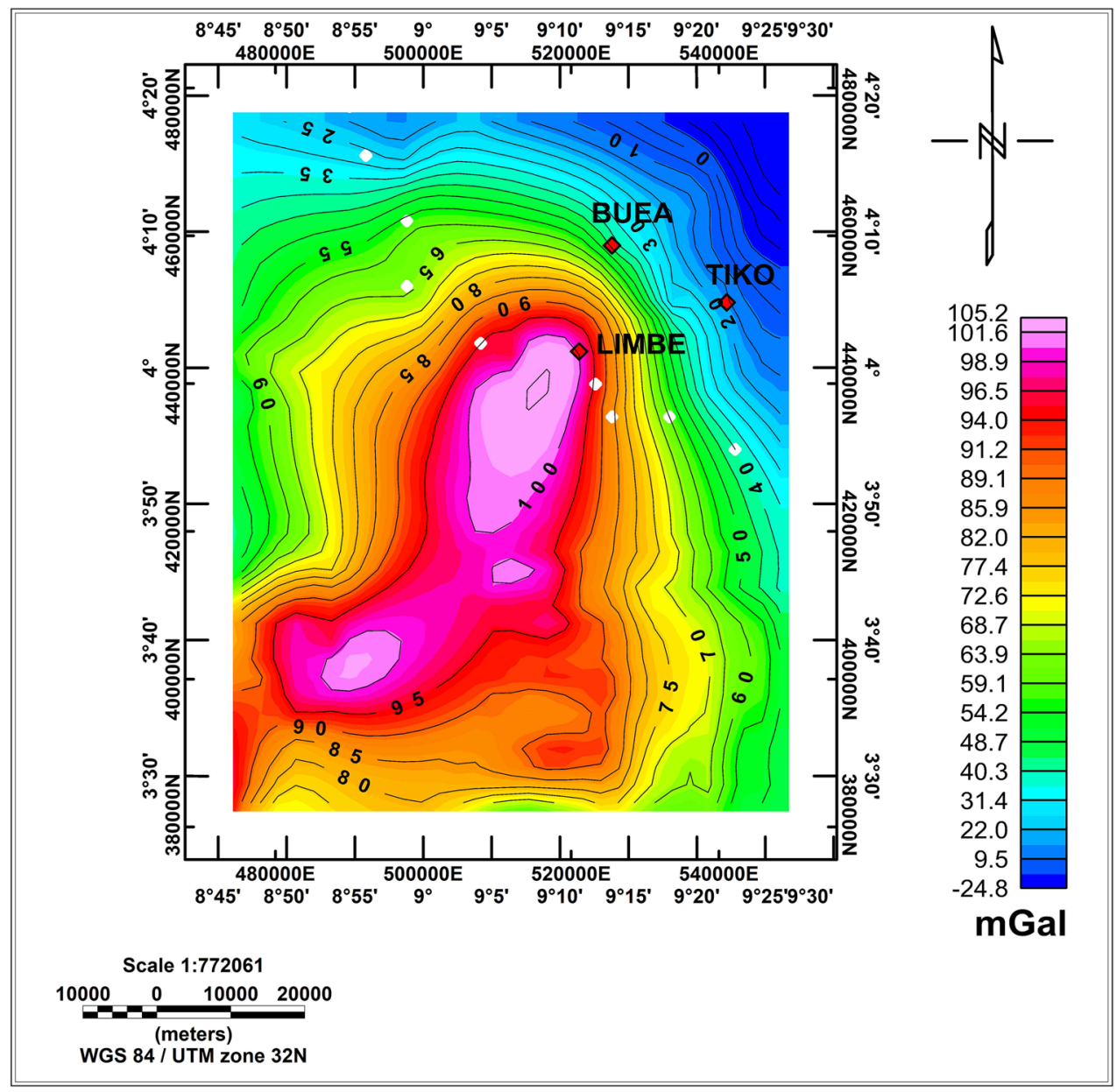

obtained from measurements corrected for the effect of the lunisolar tidal and instrumental drift (assumed to be linear in time); then, free-air reduction referenced to the ellipsoid and an infinite plate reduction with a constant reduction density of $2.67 \mathrm{~g} / \mathrm{cm}^{3}[34,40]$ were applied. These data have an accuracy of about $\pm 0.5 \mathrm{mGal}$.

For this study, a total of 183 data points were processed. These data points lay between latitudes $3^{\circ} 27^{\prime} \mathrm{N}$ and $4^{\circ} 18^{\prime} \mathrm{N}$ as well as longitudes $8^{\circ} 37^{\prime} \mathrm{E}$ and $9^{\circ} 28^{\prime} \mathrm{E}$. This study area completely engulfs a high positive anomaly extending beyond the north west portion of the Douala sedimentary basin expressed as ring-like contours on the Bouguer anomaly map (Fig. 2). The study area extends over about $94 \mathrm{~km}$ to the east and $90 \mathrm{~km}$ to the north.

\subsection{Euler 3D deconvolution}

The montaj Euler 3D Deconvolution (Euler 3D) system is an automatic location and depth determination software package for gridded magnetic and gravity data [41]. It employs two methods for Euler deconvolution, namely the standard Euler deconvolution and the located Euler deconvolution. Reid et al. [42] extended the standard Euler deconvolution method that was first described by Thompson [43] to obtain solutions by inverting Euler's homogeneity equation over a window of data at every grid point. This makes it possible to generate solutions that are free of anomalies or on the edge of anomalies, even if it is inappropriate to do so. This standard Euler method has an unchanging window size creating a bias toward solutions that are in magnitude, or the order of the window size [42]. On the other hand, the located Euler deconvolution method instead begins by calculating the analytical signal, locating peaks in this signal and then applying these locations to do Euler deconvolution. The solutions produced by this method are far fewer than those of the standard Euler deconvolution method. In this study, the standard Euler deconvolution method has been used. To be more explicit, the standard Euler 3D method is based on Euler's homogeneity equation which relates the potential field (gravity or magnetic) and its gradient components to the source location. This is done with a degree of homogeneity $N$, referred to as the structural index [41] which is a measure of the rate of change of a field with distance. 
Table 1 Structural index values for different magnetic and gravity geologic models

\begin{tabular}{llll}
\hline Geologic model & $\begin{array}{l}\text { Number of infi- } \\
\text { nite dimensions }\end{array}$ & Magnetic SI & Gravity SI \\
\hline Sphere & 0 & 3 & 2 \\
Pipe & $1(z)$ & 2 & 1 \\
Horizontal cylinder & $1(x-y)$ & 2 & 1 \\
Dyke & $2(z$ and $x-y)$ & 1 & 0 \\
Sill & $2(x$ and $y)$ & 1 & 0 \\
Contact & $3(x, y$ and $z)$ & 0 & Undefined \\
\hline
\end{tabular}

Thus, for a potential field $R(u, v, z)$, Euler's equation can be stated as:

$\left(u-u_{0}\right) \frac{\mathrm{d} R}{\mathrm{~d} u}+\left(v-v_{0}\right) \frac{\mathrm{d} R}{\mathrm{~d} v}+\left(z-z_{0}\right) \frac{\mathrm{d} R}{\mathrm{~d} z}=N(C-R)$

where $\left(u_{0}, v_{0}, z_{0}\right)$ is the location of the potential field whose total field $R$ is measured at $(u, v, z)$ and has a regional value of $C . N$ of course is the structural index (SI).

It was shown by Reid et al. [40] that an SI index of 0.5 will be obtained for a magnetic contact if an offset $A$ is introduced to incorporate anomaly amplitude, strike and dip factors, i.e.,

$\left(u-u_{0}\right) \frac{\mathrm{d} R}{\mathrm{~d} u}+\left(v-v_{0}\right) \frac{\mathrm{d} R}{\mathrm{~d} v}+\left(z-z_{0}\right) \frac{\mathrm{d} R}{\mathrm{~d} z}=A$

Consequently, an optimum source location $\left(u_{0}, v_{0}, z_{0}\right)$ can be determined for a set of observed total field data by solving Euler's equations for a given index by least squares inversion of data. It is this inversion process that is usually called Euler deconvolution.

The different SI values for simple models in magnetic and gravity fields are given in Table 1.

The Euler 3D system uses a least squares method to solve Euler's equation simultaneously for each grid position within a sub-grid (window). A solution is recorded if the depth uncertainty of the calculated depth is less than a specified tolerance and the solution is within a limiting distance of the center of the data window. Upon completion of a process, an output is obtained consisting of the database file containing the depth solutions.

It is important to note that it can be shown that an index value that is too low gives depths that are too shallow while that which is too high gives depth estimates that are too deep. Depth estimates are more precise for high-index sources than for low sources even if the index is correct. Euler deconvolution being a statistical process, the solution has positions which have associated uncertainties with the depth uncertainty and location uncertainty reported as a percentage of the depth.
It is important to state that, according to [41], since the SI value for geologic contacts is undefined, the solution is to work with the first vertical derivative of the gravity field in place of the original gravity field. When this is done, this makes the gravity SI equivalent to the magnetic SI for the same model source. In this light, when the first derivative for the gravity field is used for an SI value of 0 , the results correspond to those of geologic contacts. It is also worth noting that for an SI value of 0 , an index value of 0.5 can be used to obtain reasonable results in practice. The different SI values were therefore employed on the residual field and its derivative to be able to appropriately image their geologic sources.

\subsection{Source edge detection (SED)}

Geological contacts of possible source bodies in the study area were analyzed using another tool by Oasis montaj version 8.3.3 known as the source edge detection (SED) function. This tool is able to locate edges (geological contacts) or peaks from potential field data by analyzing the local gradients [41]. It is a function that uses the procedure of identifying maxima on a grid of horizontal gradient magnitudes to estimate the location of abrupt lateral changes in magnetization or mass density of upper crustal rocks. The SED function employs different Geosoft Executable (GX) files to attain its aim. It uses the SEDgridgrad_H.GX executable file to calculate the total horizontal derivative (i.e., gradient) grid from the input grid which is typically a Bouguer or residual gravity grid. This total horizontal derivative result is produced using a $3 \times 3$ point convolution filter. Next, the SEDpeak2.GX executable file is used to locate the approximate edges and down-gradient directions of source bodies from the gravity grids. It uses the method of Blakely and Simpson [44] to find localized peaks in a grid. It compares the value of each grid cell with those of the eight surrounding grid cells in four directions $(x$, $y$ directions and both diagonals) before considering the grid cell. Four different levels exist in order to determine whether a grid cell can be selected as a peak:

'all 4 directions': grid values in all adjacent grid cells are lower.

' $3 / 4$ directions': grid values in three directions are lower. '2/4 directions': grid values in two directions are lower. ' $1 / 4$ direction': grid values in any one direction are lower (i.e., a ridge).

The more the directions, the fewer the peaks while the $1 / 4$ direction option presents all the ridges. Depending on the geological responses and noise levels, the 4 or $2 / 4$ options may be better for some data sets, but a peak value of 3 usually works best. 
Since this study seeks to carry out a general investigation of possible geological bodies and characterize them, grid values shall be sought for options $2 / 4$ and above.

Finally, to plot the source edges with peak levels colorcoded, the SEDsymbplot.GX can be used. When it is plotted, the strike direction of the edge (contact) is shown by the direction of the long axis, while the 'down-gradient' direction, which points away from the source which is locally more dense or magnetized, is indicated by the dip indicator. For a plot done over the original grid, the symbols will trace the geological contacts, whereas in the case of a plot over the total horizontal gradient grid, the symbols trace the local peaks.

\subsection{Special function analysis}

The special functions used in this study are made up of one model-specific special function, the horizontal gradient magnitude (HGM) and two model-independent functions, namely the analytic signal (AS) and the local wavenumber (LW). Model-specific special functions are used to estimate locations of very specific isolated source types while model-independent special functions are used to estimate the locations of a variety of different isolated source types from either observed or transformed potential fields [45].

(a) The horizontal gradient magnitude (HGM) is defined as:

$\operatorname{HGM}(x, y)=\sqrt{\left(\frac{\partial P}{\partial x}\right)^{2}+\left(\frac{\partial P}{\partial y}\right)^{2}}$

where $P$ is the observed field.

The HGM was the first special function to be used in locating contacts and faults from gravity, pseudogravity or reduced-to-the pole magnetic data [46]. Over the edges of horizontal sheets, HGM attains a peak for gravity data and takes the form:

$P(x)=\frac{A}{X^{2}+Z^{2}} \quad$ or $\quad P(x, y)=\frac{A}{X^{2}+Y^{2}+Z^{2}}$

where $X=\left(x-x_{0}\right), Y=\left(y-y_{0}\right), Z=\left(z-z_{0}\right)$ and $\left(x_{0}, y_{0}, z_{0}\right)$ is the source location.

Apart from horizontal sheet sources which can be reliably located using peaks or ridge crests of HGM, multiple peaks or peak offsets will be produced by other source types using gravity data.

(b) The analytic signal (AS) is defined for gridded data as:
$\mathrm{AS}(x, y)=\sqrt{\left(\frac{\partial P}{\partial x}\right)^{2}+\left(\frac{\partial P}{\partial y}\right)^{2}+\left(\frac{\partial P}{\partial z}\right)^{2}}$

The AS, also known as the total gradient (TG), of a potential field can be used to estimate horizontal locations and strikes of sources since it peaks over isolated $2 \mathrm{D}$ and some 3D sources [47].

(c) The local wavenumber (LW) is defined by $[48,49]$ as:

$\operatorname{LW}(x, y)=\frac{\frac{\partial^{2} P}{\partial x \partial z} \frac{\partial P}{\partial x}+\frac{\partial^{2} P}{\partial y \partial z} \frac{\partial P}{\partial y}+\frac{\partial^{2} P}{\partial z^{2}} \frac{\partial P}{\partial z}}{\left(\frac{\partial P}{\partial x}\right)^{2}+\left(\frac{\partial P}{\partial y}\right)^{2}+\left(\frac{\partial P}{\partial z}\right)^{2}}$

For isolated 2D sources as well as for some 3D sources:

$\operatorname{LW}(x)=\frac{-(S I+1) Z}{X^{2}+Z^{2}}$

where $\mathrm{SI}$ is the structural index [50].

This relation (6) makes LW ideal for estimating source location, depth, strike and structural index.

Philipps et al. [45] showed that local curvature in small data windows can be used to locate the peaks and ridges of special functions and estimate the source location, depth and strike. They established that for analytic signals, better results are obtained from the half vertical integral and a structural index value of 0.1 , while for the local wavenumber, better results (though with deeper depth estimates) are calculated from the first vertical integral. Comparing results from these special functions in the estimation of contact and fault locations over a study area, it was established that AS and LW solutions typically plot close together while HGM solutions tend to be the most coherent and most easily interpreted. Nevertheless, HGM solutions are typically offset from those of AS and LW mostly due to non-vertical dips on the faults and contacts. This offset of the HGM solutions should be in the downdip direction.

\section{Results and discussions}

\subsection{Qualitative analysis}

The Bouguer anomaly map (Fig. 2) was obtained by gridding the data using the minimum curvature grid and then plotted with contour intervals of $3 \mathrm{mGal}$. It had been shown earlier on [13] that the optimum height of upward continuation required to completely carry out a residual-regional separation in this area of study is equal 
Fig. 3 Residual anomaly map for the north west portion of the Douala sub-basin. The white dots represent approximately the boundary between the continent and the Atlantic Ocean

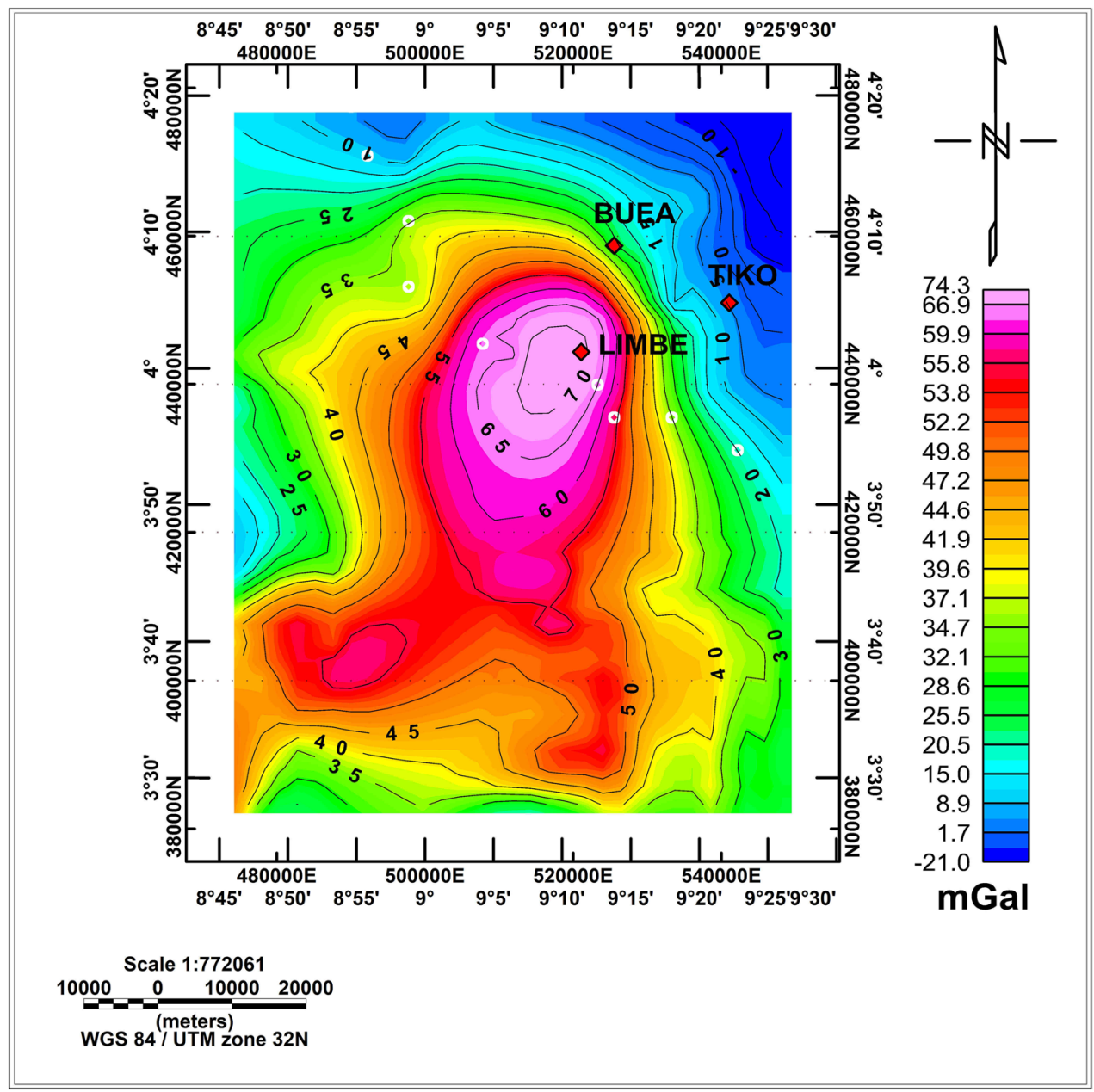

to $30 \mathrm{~km}$. The residual anomaly map for an upward continuation height of $30 \mathrm{~km}$ was therefore generated and is plotted in Fig. 3.

The Bouguer anomaly map indicates ring-like contours with a major peak (with value of about $105 \mathrm{mGal}$ ) located around longitude $9.2^{\circ} \mathrm{E}$ and latitude $3.9^{\circ} \mathrm{N}$. Two other minor peaks do exist to the south of the main peak. The density varies from a peak high gravity value from the center of this study region and diminishes in all directions from the center. The variation is gradual for most parts of the region, but there is a sharp change to the north east portion of the plot which is suggestive of a rapid change in structure. The variation in density presents approximately three major zones of anomaly which moves from very high positive anomaly zone in the center through an average positive zone to an average negative zone. Contour lines to the north and south of the area of study are generally W-E in orientation, while to the east and to some extent to the west, they are oriented approximately NNW-SSE. The residual anomaly map on the other hand is very similar in characteristics to the Bouguer anomaly map but for some slight differences. It has a peak value of about
$74.29 \mathrm{mGal}$ around longitude $9.17^{\circ} \mathrm{E}$ and latitude $4^{\circ} \mathrm{N}$. The concentric circular contours which culminate to the peak value are suggestive of an intrusive body in this area. This residual is also marked by three main zones of anomaly with a transition from a peak positive gravity anomaly with range from about 39 to $74 \mathrm{mGal}$ through an average positive zone with range of about 15 to $38 \mathrm{mGal}$ to a low density zone gravity anomaly ranging from about -8.8 to $14 \mathrm{mGal}$. Contours surrounding the zone with high positive gravity anomaly are having similar orientations to those on the Bouguer anomaly map. Here again, an abrupt change in anomaly value to the north east portion of the high positive zone is noticed which still emphasizes the northern limit of the intrusive body. The gentle change in variation in residual anomaly to the other sides of the high positive zone suggests that the intrusive body extends in these directions or has limits whose slopes are not very stiff. The portions of the zone surrounding the high positive zone whose contours are almost parallel in nature are possible areas where geologic contacts or lineaments can be found. On the residual anomaly map, one of the minor peaks observed on the Bouguer map is almost merged to 

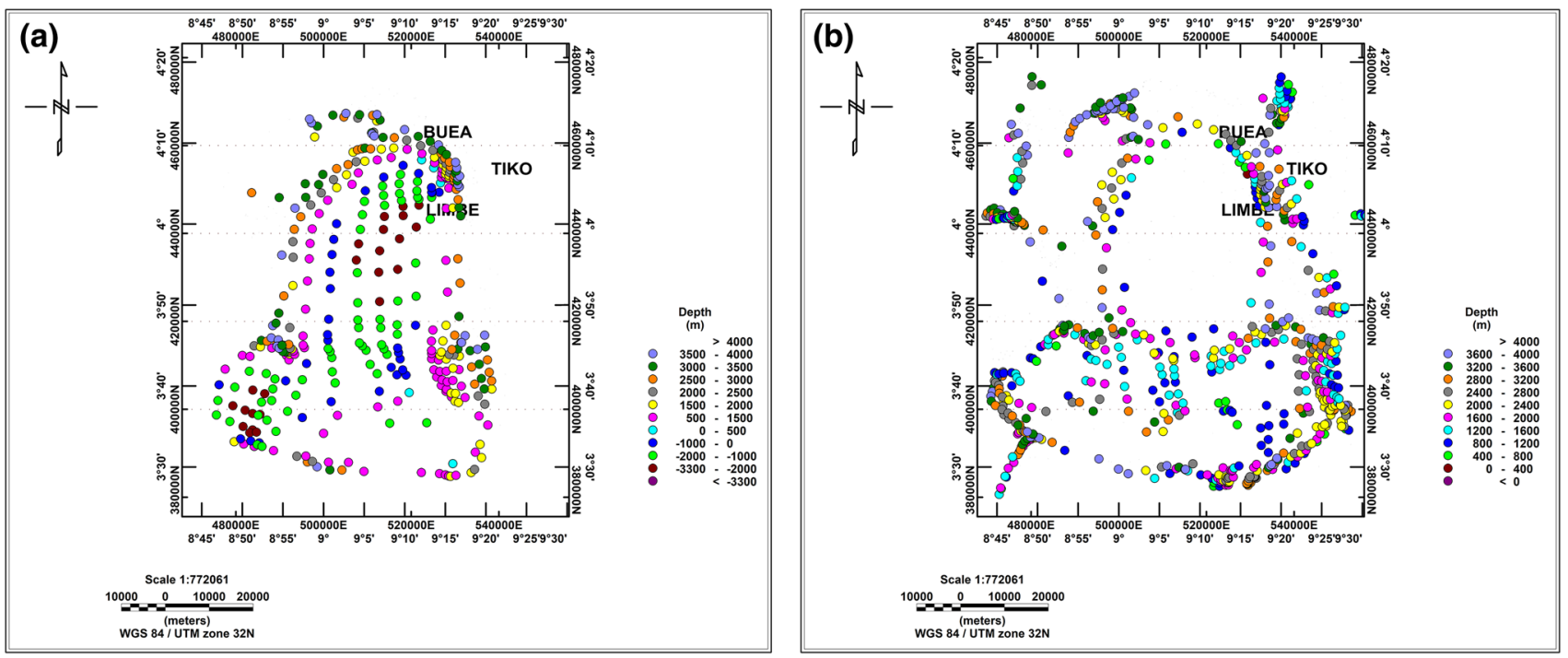

Fig. 4 Solution of Euler 3D deconvolution for structural index $=0$ plotted for depth positions less than $4 \mathrm{~km}$ on $\mathbf{a}$ Bouguer anomaly field, $\mathbf{b}$ vertical derivative of Bouguer anomaly field

the main peak while the other still stands out isolated. Two other small peaks are also noticed. It is probable that all the minor peaks noticed are all parts of the same intrusive body whose depth varies laterally such that it has different peaks at different depths with the shallowest depth being that with the greatest peak value on the Bouguer and residual anomaly maps.

\subsection{Euler 3D solutions}

Euler 3D has been applied on gravity data in this study area in order to determine the depth to the top of the geologic sources which produce the observed anomalies on the Bouguer and residual anomaly maps.

From the works of $[13,14]$, results of spectral analysis which were further backed by those of 2.5D modeling suggested the presence of an intrusive body of density $2.77 \mathrm{~g} /$ $\mathrm{cm}^{3}$ of igneous origin in this study area located at a depth of about $4.2 \mathrm{~km}$. This body was shown to have a thickness of about $26 \mathrm{~km}$. Consequently, all other possible geologic sources are expected to exist to a maximum depth of about $4.2 \mathrm{~km}$ from the ground surface in this area. It is in this light that the Euler 3D method has been applied on Bouguer anomaly map as well as on the vertical gradient of the Bouguer anomaly map for a structural index value of 0 . The results have been plotted for depth positions with values less than $4 \mathrm{~km}$ and values greater than $4 \mathrm{~km}$ in order to be able to highlight geologic bodies above the intrusive body and also to outline the intrusive body below this depth. Results of Euler 3D plots in both 2D and 3D views are presented in Figs. 4 and 5. The 3D plot presents the depth positions in an axis system where the z-axis (depth axis) is pointing vertically upwards.

When solutions of the Euler 3D deconvolution from both the Bouguer anomaly field and its vertical derivative are plotted for depth positions located above $4 \mathrm{~km}$ (Figs. $4 a$, $b$ and $6 a$ ), they both indicate the presence of geologic contacts of varying depths and orientations. These plots don't indicate very distinctly the characteristics of specific contacts in terms of their individual alignments and orientations though some N-S, NE-SW and E-W trending as well as fault signatures of different strike directions and depths are suggested on these plots.

Plots for depth positions greater than $4 \mathrm{~km}$ (Figs. 5a, b and $6 \mathrm{~b}$ ) clearly portray the outline of a near circular geologic body which extends deep into the crust beneath this study area. This of course confirms the presence of a deeper structure of intrusive origin [13, 14]. The absence of depth location plots toward the south of these plots further suggests that this intrusive body in its southern section stretches beyond this study area.

\subsection{Source edge detection solutions}

The source edge detection method (SED) has been employed on the Bouguer anomaly data in this study area in order to highlight possible edges or peaks from the potential field generated by geologic models. In the first phase of the analysis, SED was carried out for directions of $2 / 4$ and above, on the entire Bouguer anomaly field of the study area and the solutions plotted on both the Bouguer anomaly map and the horizontal derivative of the Bouguer anomaly map (Figs. 7 and 8). This was in view of obtaining 

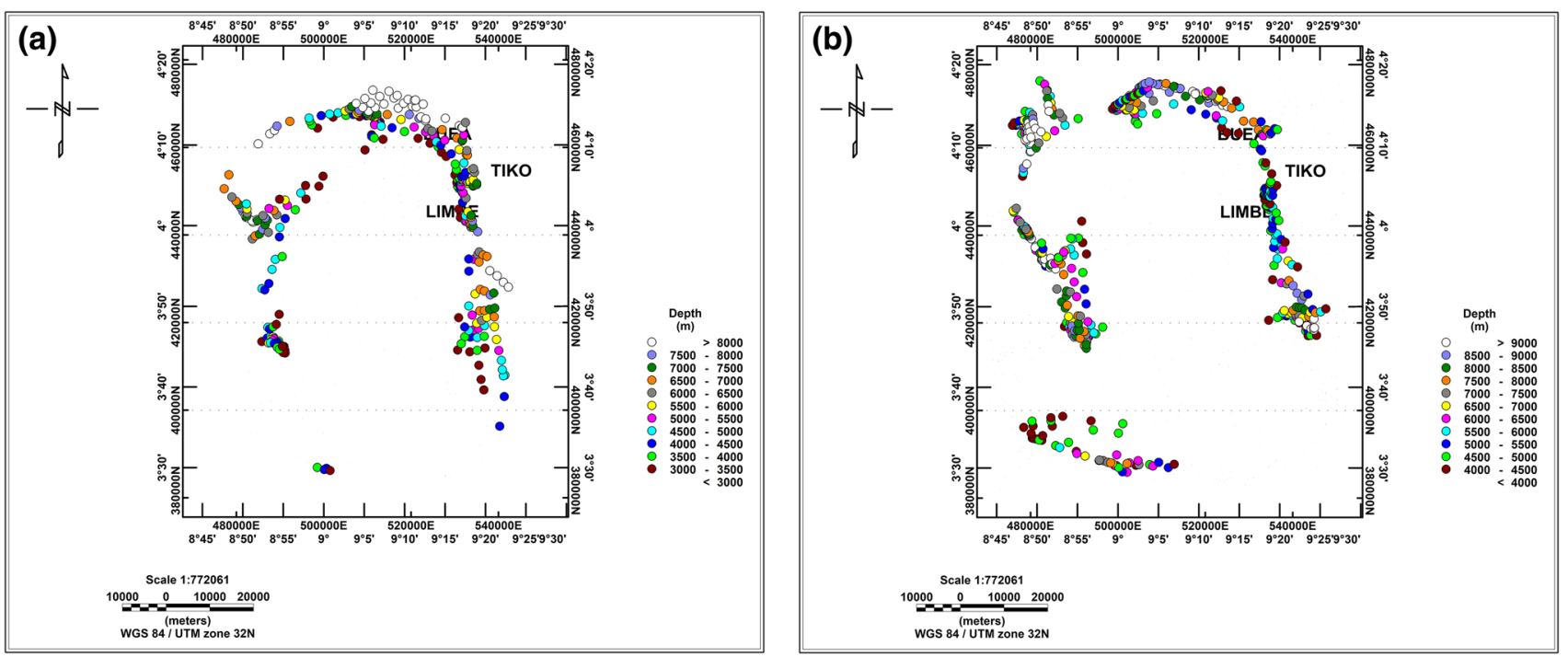

Fig. 5 Solution of Euler 3D deconvolution for structural index $=0$ plotted for depth positions greater than $4 \mathrm{~km}$ on, a Bouguer anomaly field, b vertical derivative of Bouguer anomaly field

Fig. 6 Solution of Euler 3D deconvolution for structural index $=0$ plotted in 3D view for depth positions greater than $4 \mathrm{~km}$ on a Bouguer anomaly field, $\mathbf{b}$ vertical derivative of Bouguer (in the 3D views, depth is plotted vertically upward as positive)
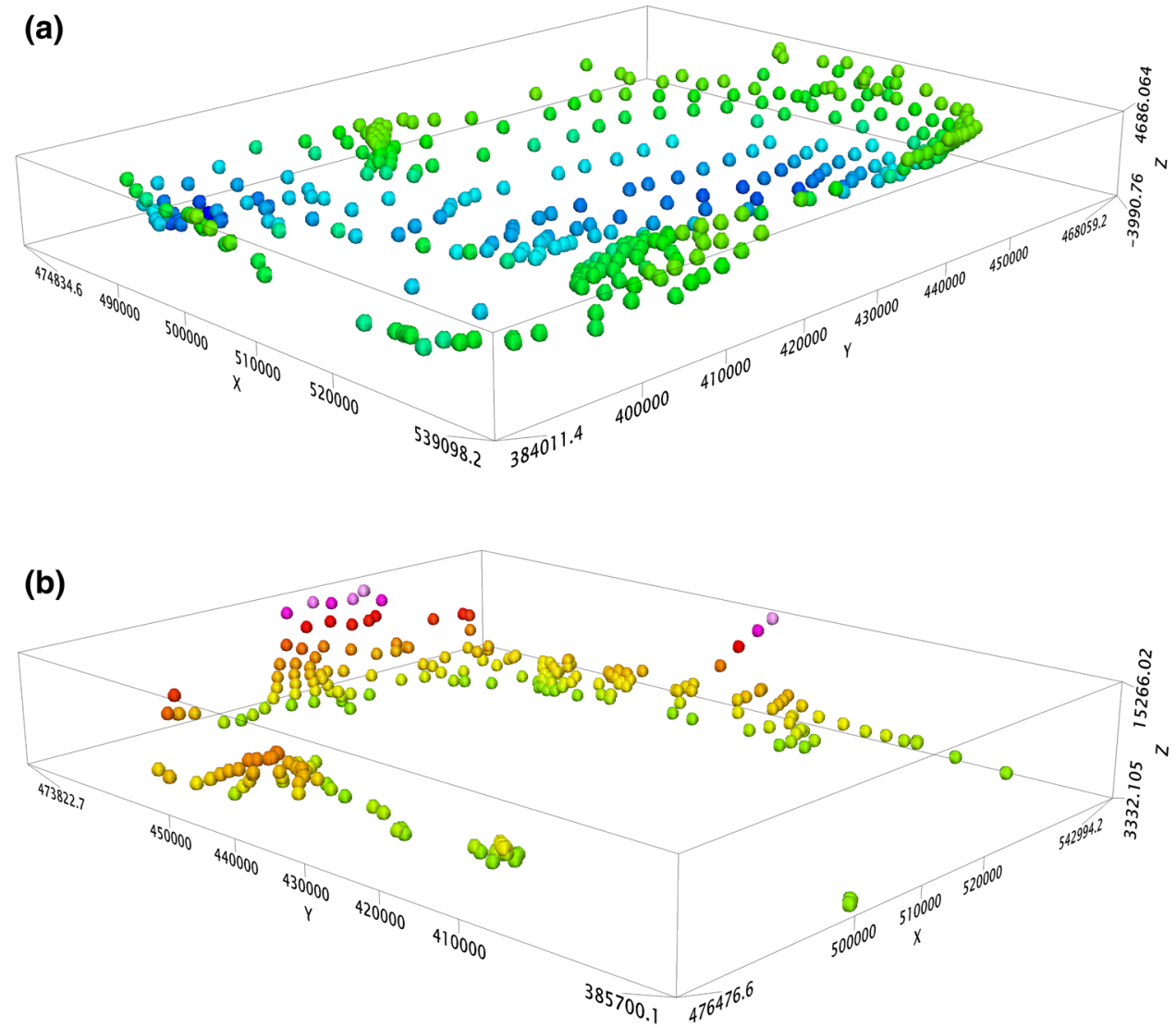

an overview of the behavior of source edges in the study area. Note that on all these plots of source edges with peak levels color-coded (Figs. 16, 17, 18, 19, 20, 21), the symbol used $((\perp))$ denotes that the strike direction of the edge is represented by the direction of the long (horizontal) axis, while the 'down-gradient' direction, which points away from the source that is locally more dense, is indicated by the dip indicator (vertical short axis). 
Fig. 7 SED plots for the Bouguer anomaly field. The peak color-coded symbol $((\perp))$ is red for peak value 2 , black for peak value 3 and white for peak value 4 . White dots represent the approximate boundary between the continent and the Atlantic Ocean

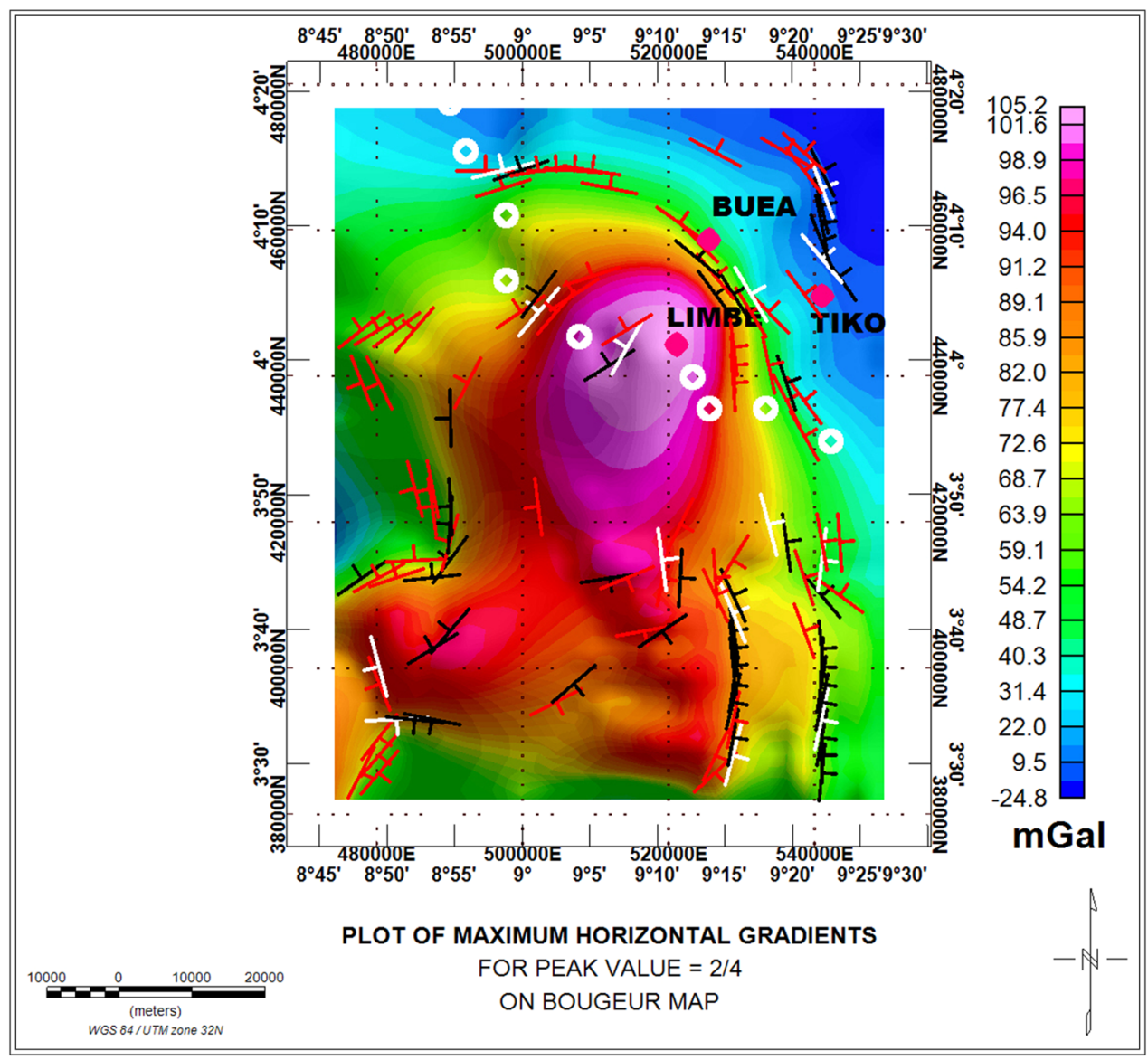

The solution of SED plotted on the Bouguer anomaly field for peak values of maximum horizontal gradients ranging from 2 to 4 (Fig. 7) presents source edges resulting from both shallow and deep geologic structures whose general behavior seems to have been overshadowed by the outlines of the deeper and more massive underlying intrusive body. It can be seen that the presented edges in the outlines, for most of them, are along the lines of transition between the three major zones of anomaly peaks noticed on the Bouguer anomaly map (Fig. 2). The presence of different levels of peaks along the same alignments suggests that these outlines are not uniform in structure. Considering also that, between these major transitions, other edge plots are sparingly located at some positions on the Bouguer map; there appear to be undulations in the inclination of points on the surface of this intrusive body lying underneath. These edges are further emphasized to be peaks of horizontal gradients when plotted on the horizontal gradient map of the Bouguer anomaly field (Fig. 8).

Generally, edges with peak values equal to 4 (implying it changes in all four directions) are least in number (white in color) on these plots and can be found among others, at all the positions where the major and two minor peak values were observed on the Bouguer and residual anomaly maps. The edges with peak value equal to 3 are a little bit greater in number than those with value 4 and located with emphasis around positions where peaks with value 4 are located. The edges with value 2 are the greatest in number and very widely spread suggesting the undulating nature of the surface of the geologic body in this area of study.

To further verify the nature of these edges generated by SED in relation to their behavior with depth, the edges for heights of upward continuation equal to $1 \mathrm{~km}, 4 \mathrm{~km}$, $7 \mathrm{~km}$ and $12 \mathrm{~km}$ were generated. These were then plotted on the horizontal derivative maps obtained at these very upward continuation heights (Figs. 9, 10, 11, 12).

With increasing depth, the plot of the edges became more concentrated and uniformly aligned emphasizing major portions to the NE, SE and SW of the peak major anomaly zone. These portions correspond to the spots where the Bouguer and residual anomaly fields around the major peak anomaly zone registered sharp changes in their orientations. These emphases are noticed up to the upward continued height of about 6 to $7 \mathrm{~km}$. According to [7], which showed that the depth to the top of an anomaly source after upward continuation at a height $h$ is greater 
Fig. 8 SED plots for the horizontal derivative of the Bouguer anomaly field. The peak color-coded symbol $((\perp))$ is red for peak value 2 , black for peak value 3 and white for peak value 4. White dots represent the approximate boundary between the continent and the Atlantic Ocean

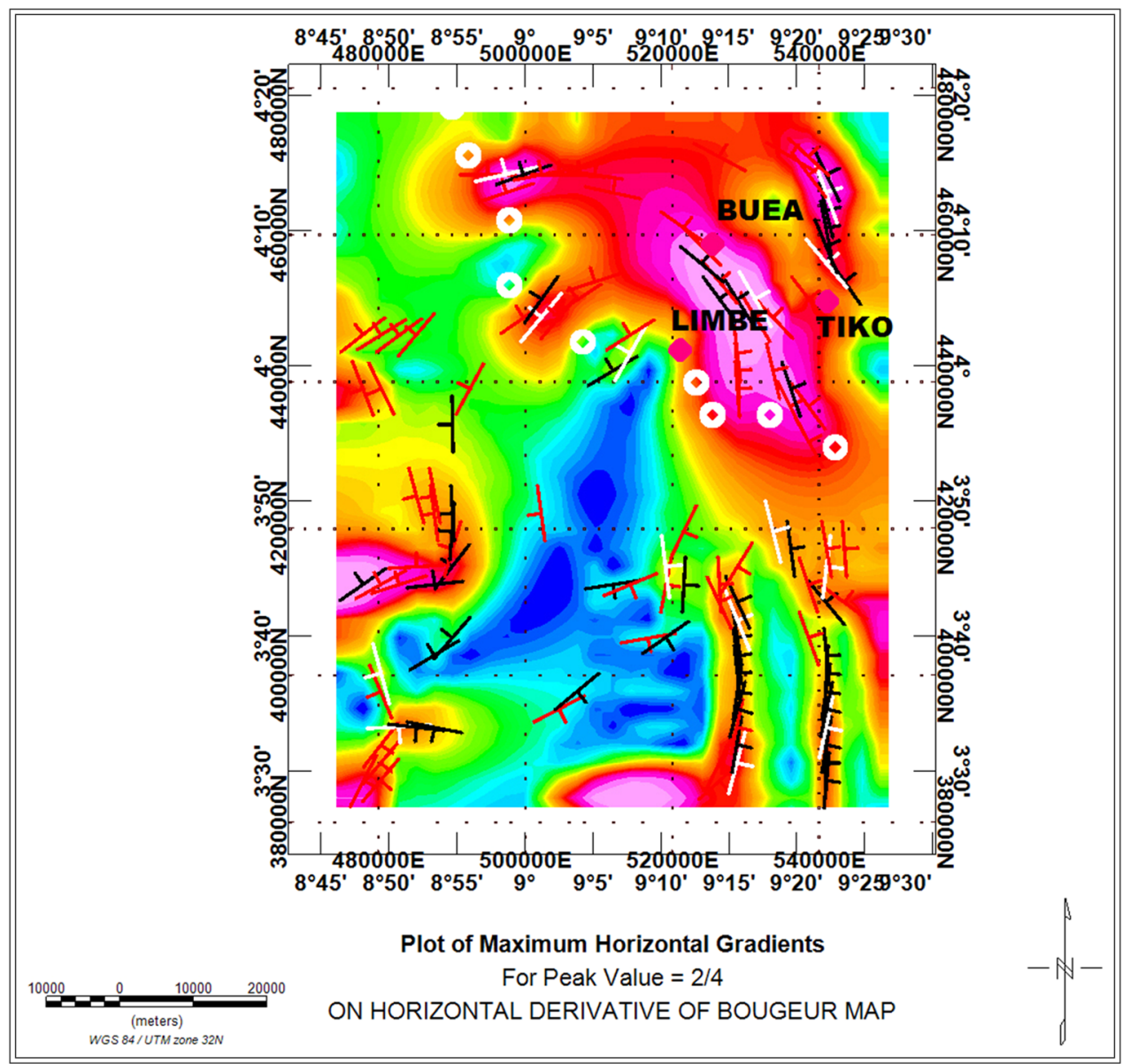

or equal to $\mathrm{h} / 2$, the body in this zone of study would be located at a depth of $3.5 \mathrm{~km}$ or more. This depth is not very different from the suggested depth of the intrusive body; therefore, the noticed emphasis is most likely associated with it. From this depth downward, the plots start reducing greatly in number up to about $12 \mathrm{~km}$ where only the northern limit bounding the spherical geologic model (located between longitudes $9^{\circ} 7^{\prime}$ and $9^{\circ} 15^{\prime} \mathrm{E}$ and between latitudes $3^{\circ} 55^{\prime}$ and $4^{\circ} 10^{\prime} \mathrm{N}$ ) observed in Figs. 11 and 12 is left. This limit appears to have a relatively sharp slope while to the west and east the slopes are much gentle.

These results from the upward continued fields confirm the presence of the intrusive body from a depth of about $4 \mathrm{~km}$ downwards, whose northern, eastern and western limits fall within this study area, though with different slope variations. The absence of edges toward the southern limit of the study area for deeper upward continued heights suggests this body stretches southwards beyond this study area.

It was also important to generate the SED solutions for the geological bodies whose signatures are noticed to be superimposed in the overall SED plots of the Bouguer anomaly field (Fig. 7) but absent in the SED plots from the upward continued fields at heights of $4 \mathrm{~km}$ and more. To this effect, using the $1 / 4$ direction corresponding to ridges, peaks generated at upward continuous heights of $100 \mathrm{~m}$, 200 m, 400 m, 600 m, 800 m, 1000 m, 1200 m, 1400 m, 1600 m, 1800 m, 2000 m, 2200 m, 2400 m, 2600 m, 2800 m and $3000 \mathrm{~m}$ have been superimposed on the same map (Fig. 13). This plot is aimed at studying the strike and dip directions of the geological structures located at depths less than $4 \mathrm{~km}$.

These plots further emphasized the presence of the edges of numerous geological contacts of different natures, lengths and orientations. Elements of horizontal alignments in approximately $\mathrm{N}-\mathrm{S}$ and $\mathrm{E}-\mathrm{W}$ directions with different slopes suggest faults are visible on this plot. Very evident is the presence of the dip directions of the structures which generally are oriented away from the center of the study area. These seem to suggest that most of these contacts have been provoked by the upwelling of the underlying intrusive body leading to an outward displacement of its surroundings.

\section{SN Applied Sciences}




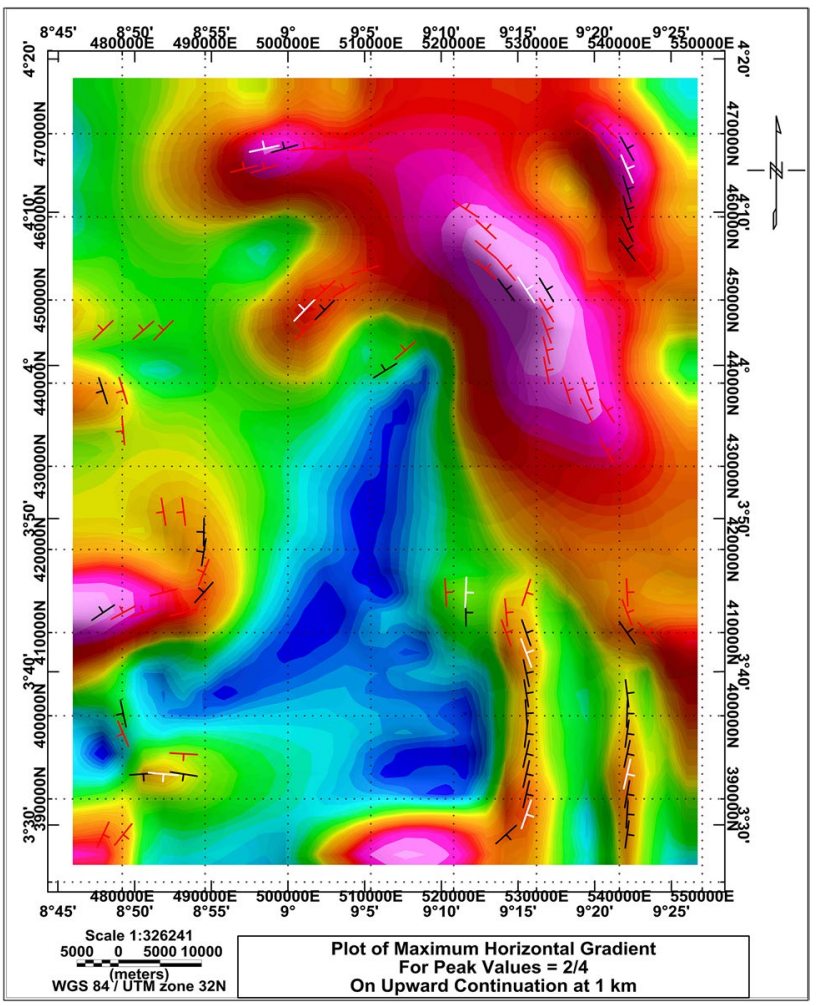

Fig. 9 SED plots from Bouguer field upward continued at $1 \mathrm{~km}$ on the horizontal derivative of the Bouguer anomaly field upward continued at $1 \mathrm{~km}$. The peak color-coded symbol $((\lrcorner))$ is red for peak value 2 , black for peak value 3 and white for peak value 4 . White dots represent the approximate boundary between the continent and the Atlantic Ocean

\subsection{Solutions from special function analysis}

In order to better characterize the geological bodies highlighted by Euler 3D deconvolution and SED in the study area for depths up to about $4 \mathrm{~km}$, the input from special function analysis was taken into consideration.

\section{HGM solutions}

The HGM map of the study area was generated (Fig. 14), and the multi-scale horizontal derivative (MSHD) method [51] was applied to determine and plot the superposition of maxima of HGM at upward continuous heights ranging from 100 to $4000 \mathrm{~m}$ (Fig. 15) and from 5000 to 30,000 m (Fig. 16). Depth solutions for HGM (Fig. 17) built on an assumed source type with vertical density contacts [45] were also generated. The HGM plot has peak values toward the NE corner and also to the W and $S$ of the study area. A NE-SW-oriented minimum portion is found around the center. Two very pronounced and parallel linear peaks

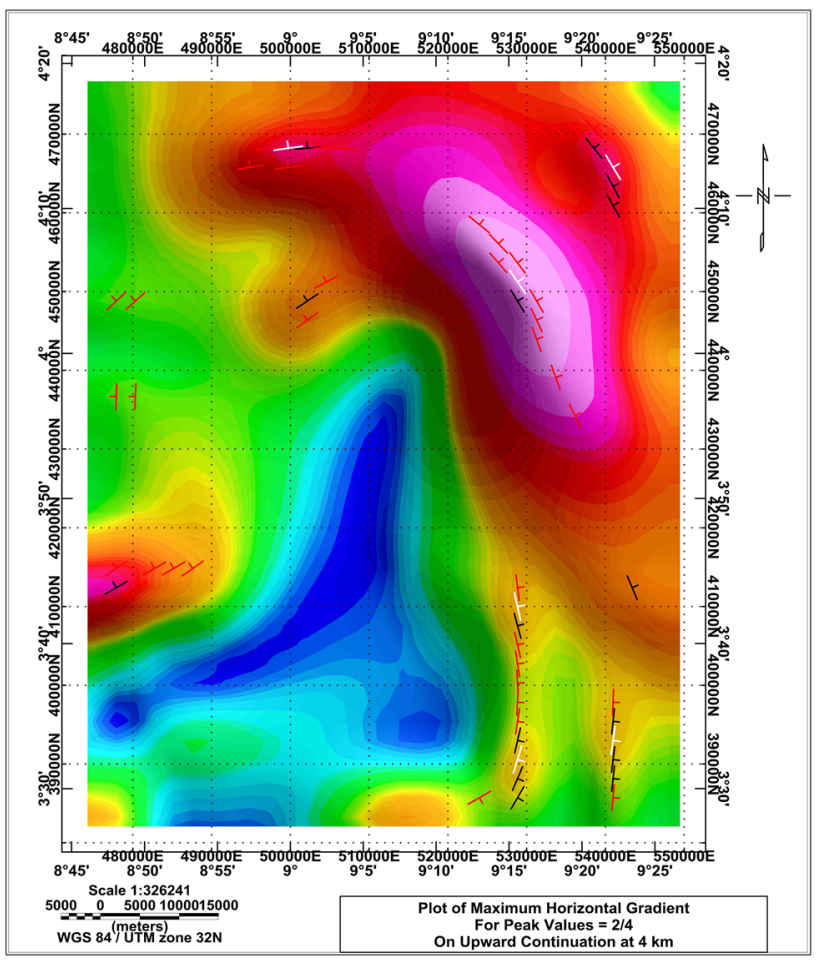

Fig. 10 SED plots from Bouguer field upward continued at $4 \mathrm{~km}$ on the horizontal derivative of the Bouguer anomaly field upward continued at $4 \mathrm{~km}$. The peak color-coded symbol $((\perp))$ is red for peak value 2 , black for peak value 3 and white for peak value 4 . White dots represent the approximate boundary between the continent and the Atlantic Ocean

are observed around the SE edge of the plot. The superimposed plots of maxima of HGM for higher continued heights (Fig. 16) present the northern, eastern and western outlines of the intrusive body. Plots for lower continuous heights highlight geologic contacts with suggested fault alignments. The depth solutions further establish these faults to be N-S, E-W, NE-SW trending with depths from about 2 to $4 \mathrm{~km}$, mostly toward the southern portion of the map. The geological contacts around the northern section of the map are mostly found at depths $5 \mathrm{~km}$ and above and are mostly approximately circular in shape with some few linear cases. This suggests that in this southern section, signatures of the intrusive body are still visible though some minor but relative deep faults are also present.

HGM depth solutions generated with source type horizontal density sheets (Fig. 18) presented a similar plot to that with vertical density contacts for positions of lineaments but assigning to them better continuity and emphasis. It nevertheless still suggests that these lineaments are buried to depths of at least $3 \mathrm{~km}$. 


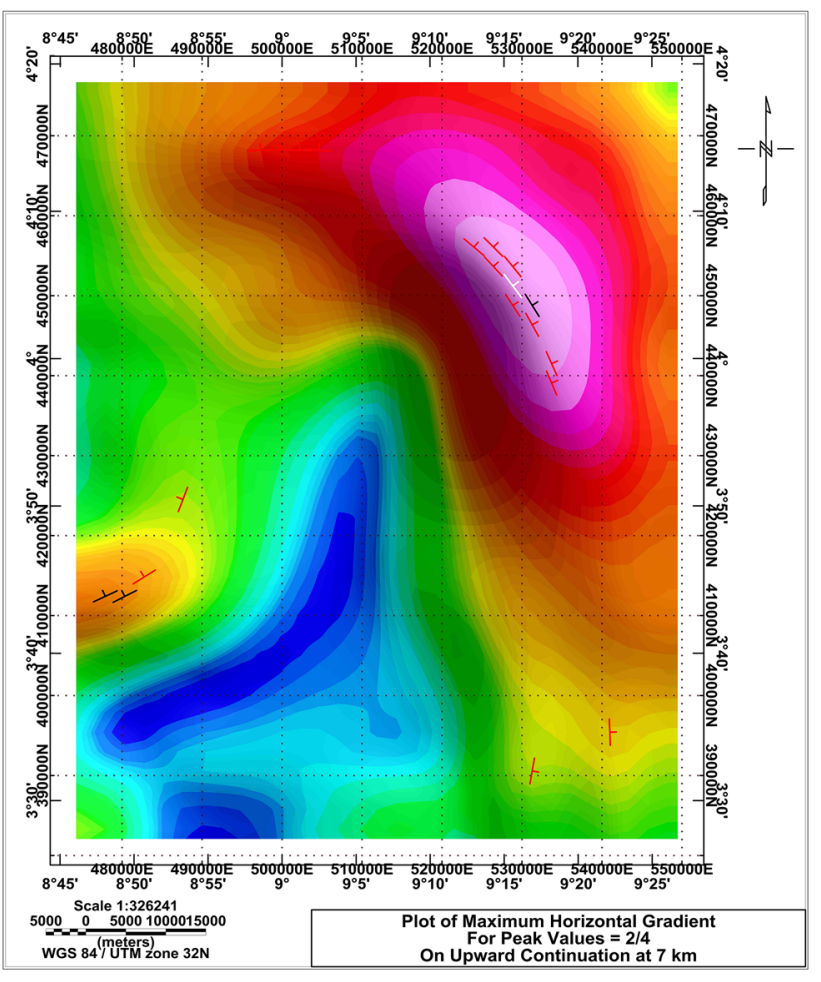

Fig. 11 SED plots from Bouguer field upward continued at $7 \mathrm{~km}$ on the horizontal derivative of the Bouguer anomaly field upward continued at $7 \mathrm{~km}$. The peak color-coded symbol $((\perp))$ is red for peak value 2 , black for peak value 3 and white for peak value 4 . White dots represent the approximate boundary between the continent and the Atlantic Ocean

\section{Comparing solutions of HGM, analytic signal and local wavenumber}

The generated Analytic signal map (Fig. 19) as well as the local wavenumber map (Fig. 20) all showed variations in features similar to the HGM map. The depth solution of the analytic signal generated from the half vertical integral and a structural index value of 0.1 (Fig. 21) and that of the local wavenumber calculated from the half vertical integral (Fig. 22) emphasized the geological contacts in the study area as suggested by depth solutions of HGM.

Superimposing the plots of the depth solutions of the analytic signal, the local wavenumber and the HGM (Fig. 23) indicates that the solutions of the analytic signal (in green) and that of the local wavenumber (in blue) plot generally close together while the HGM (in green) solutions are offset from them. This is in agreement with the results of Philipps et al. [45] who found out that the total gradient solutions from the half vertical integral and the local wavenumber solutions of total magnetic intensity typically plot close together while the HGM solutions from the reduced-to-pole field are typically offset from them. It also established that the offset of the HGM solutions

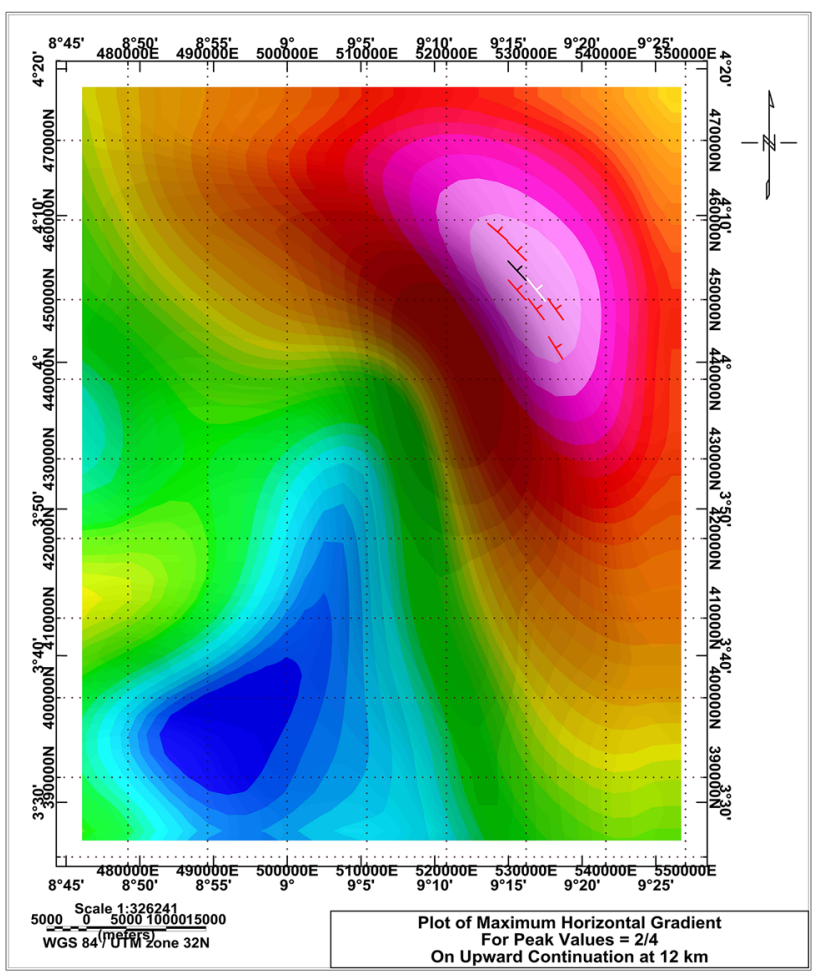

Fig. 12 SED plots from Bouguer field upward continued at $12 \mathrm{~km}$ on the horizontal derivative of the Bouguer anomaly field upward continued at $12 \mathrm{~km}$. The peak color-coded symbol $((\perp))$ is red for peak value 2, black for peak value 3 and white for peak value 4 . White dots represent the approximate boundary between the continent and the Atlantic Ocean

should be in the down-dip direction. This can be observed to be the case in the superimposed plots where the offset of the HGM is generally in the dip directions suggested by the SED solutions for upward continued heights from $100 \mathrm{~m}$ to $3 \mathrm{~km}$.

The geological contacts for depths up to about $4 \mathrm{~km}$ from the surface suggested by Euler 3D and SED solutions, and later observed on the depth solutions from the HGM, the analytic signals and the local wavenumber have been greatly emphasized on this superimposed plot. Plots from the local wavenumber (in blue) have better highlighted some contacts. This superposition of plots suggests major faults with $\mathrm{N}-\mathrm{S}, \mathrm{NE}-\mathrm{SW}, \mathrm{NW}-\mathrm{SE}$ and $\mathrm{E}-\mathrm{W}$ orientations (L1 to L8). Some minor faults with NW-SE, E-W and NE-SW orientations (L9 to L13) can also be noticed (Fig. 24). Most of the faults are located toward the southern section of the map, while around the northern section, contacts with quasi-circular signatures are observed ( 11 to $\mathrm{C} 3$ ).

The depth solutions in this study area suggest that the faults and other geological contacts are buried at a minimum depth of about $2 \mathrm{~km}$. These results are in good agreement with those of [15] which highlighted major and minor faults in the Douala sedimentary basin with 


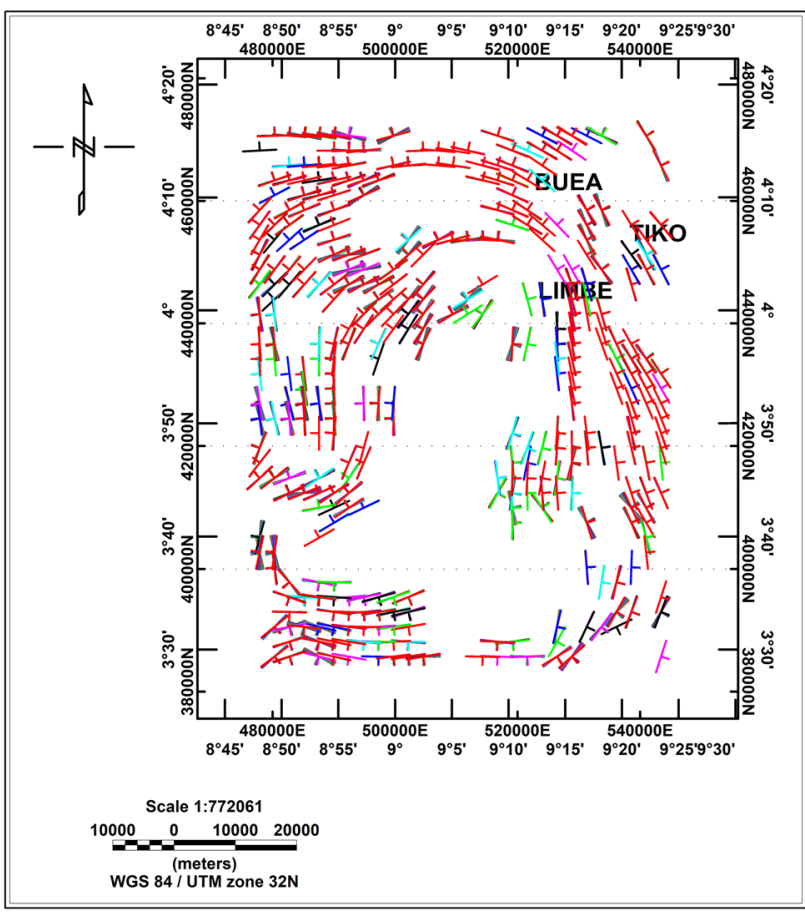

Fig. 13 Superimposed SED plots from Bouguer fields upward continued at heights $100 \mathrm{~m}$ (oxblood), $200 \mathrm{~m}$ (light brown), $400 \mathrm{~m}$ (thick green), $600 \mathrm{~m}$ (blue), $800 \mathrm{~m}$ (purple), $1000 \mathrm{~m}$ (oxblood), $1200 \mathrm{~m}$ (pink), $1400 \mathrm{~m}$ (oxblood), $1600 \mathrm{~m}$ (light brown), $1800 \mathrm{~m}$ (thick green), $2000 \mathrm{~m}$ (light brown), $2200 \mathrm{~m}$ (blue), $2400 \mathrm{~m}$ (purple), $2600 \mathrm{~m}$ (pink), $2800 \mathrm{~m}$ (red) and $3000 \mathrm{~m}$ (thick green)

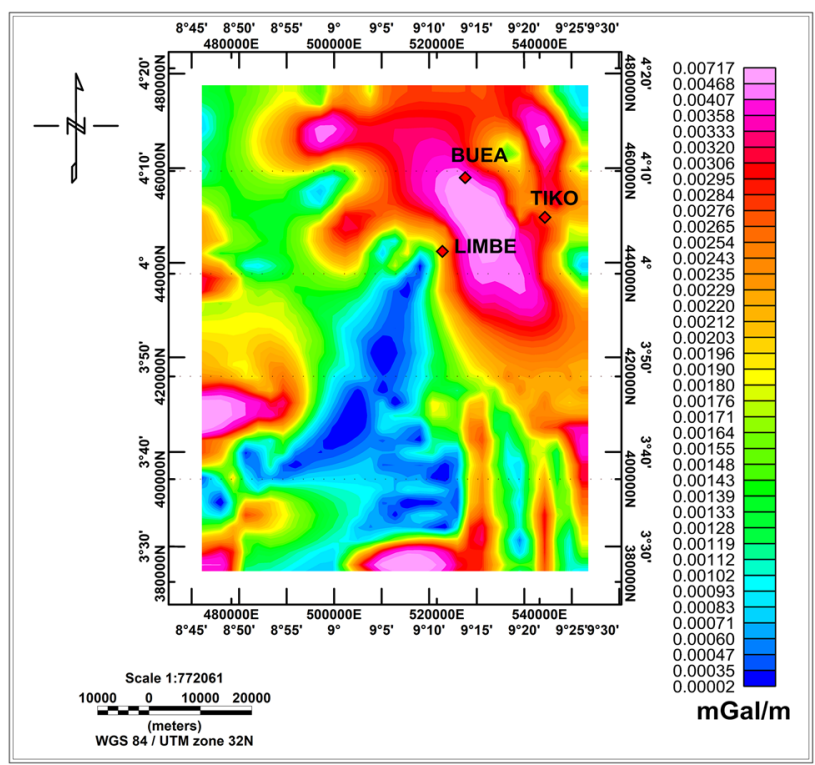

Fig. 14 HGM map of study area

NW-SE and NE-SW orientations as well as a depth of $2 \mathrm{~km}$ for the main faults. A structural index plot from the local wavenumber (Fig. 25) indicates that the majority of the

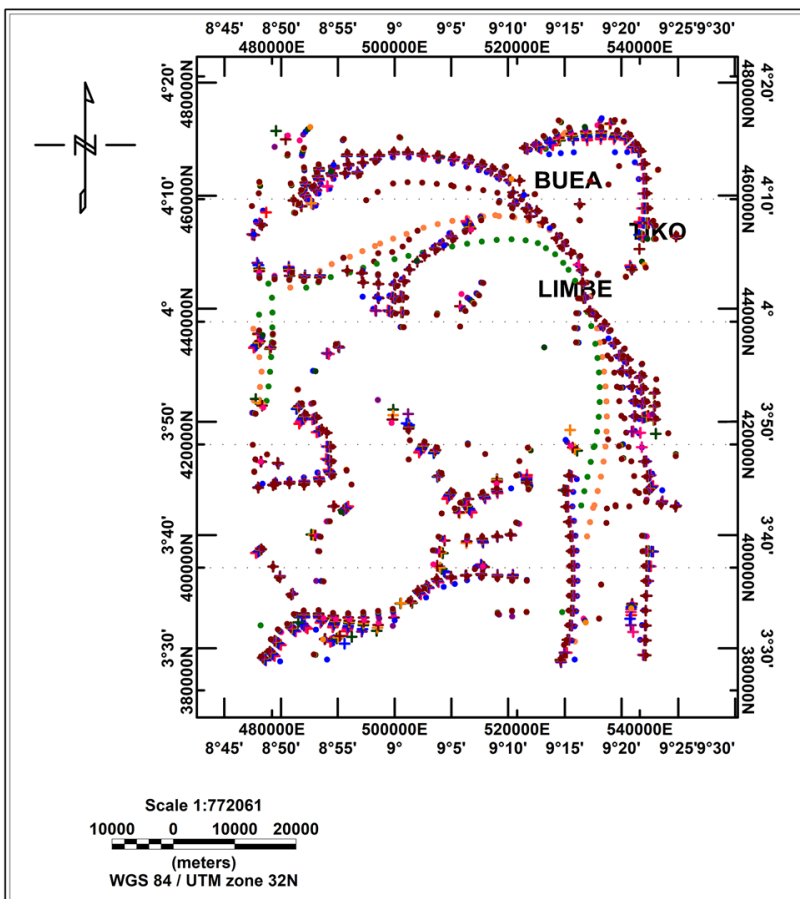

Fig. 15 Superposition of maxima of HGM at upward continuous heights ranging from $100 \mathrm{~m}$ to $4000 \mathrm{~m}$ (for circles and crosses, $100 \mathrm{~m}$ (oxblood), $200 \mathrm{~m}$ (light brown), $400 \mathrm{~m}$ (thick green), $600 \mathrm{~m}$ (blue), $800 \mathrm{~m}$ (purple), $1000 \mathrm{~m}$ (oxblood), $1200 \mathrm{~m}$ (pink), $1400 \mathrm{~m}$ (oxblood), $1600 \mathrm{~m}$ (light brown), $1800 \mathrm{~m}$ (thick green), $2000 \mathrm{~m}$ (light brown), $2200 \mathrm{~m}$ (blue), $2400 \mathrm{~m}$ (purple), $2600 \mathrm{~m}$ (pink), $2800 \mathrm{~m}$ (red), $3000 \mathrm{~m}$ (thick green), $4000 \mathrm{~m}$ (blue))

geological contacts in this study area have a structural index value in the range -0.8 to 0 .

\section{Conclusion}

The high positive gravity anomaly presented by the generated Bouguer and residual anomaly maps in the region extending from the NW portion of the Douala sedimentary sub-basin has been characterized for the possible geologic models which have given rise to these observed anomalies by using qualitative studies, Euler 3D deconvolution, source edge detection (SED) and special function analysis. The qualitative analysis indicated that the Bouguer and residual anomalies have major peak values around longitude $9.8^{\circ} \mathrm{E}$ and latitude $3.9^{\circ} \mathrm{N}$ and around longitude $9.17^{\circ} \mathrm{E}$ and latitude $4^{\circ} \mathrm{N}$, respectively, as well as two other minor peaks to the south of the main peak. Three major zones of anomaly which move from a very high positive anomaly zone in the center through an average positive zone to an average negative zone were also noticed.

Solutions from Euler 3D deconvolution as well as those of source edge detection (SED) were able to present, for 


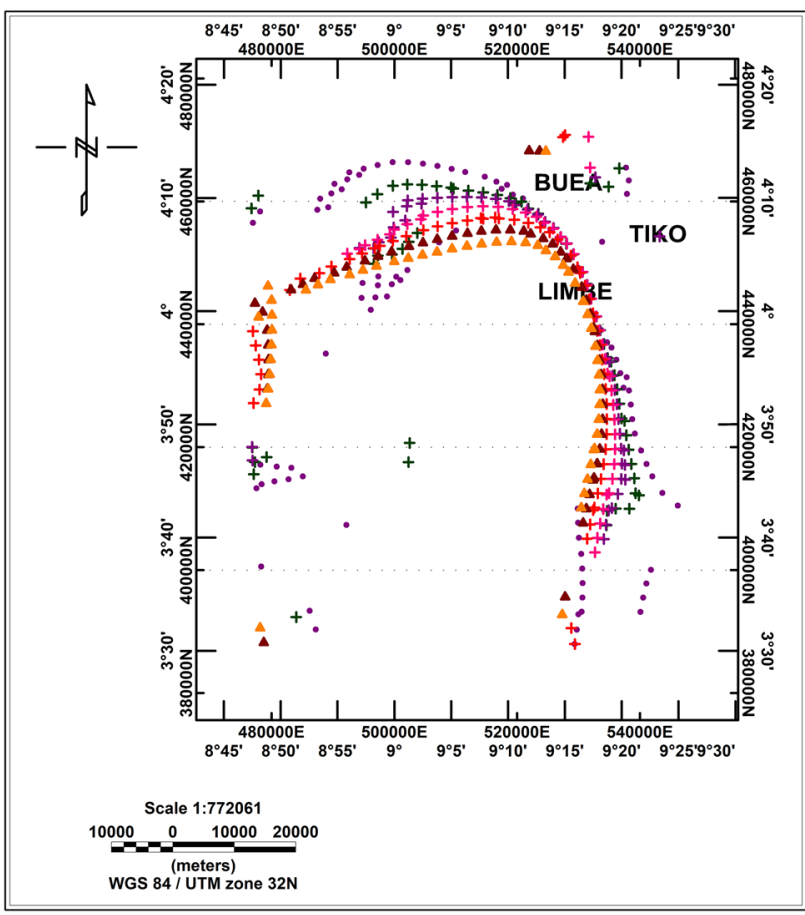

Fig. 16 Superposition of maxima of HGM at upward continuous heights ranging from $5000 \mathrm{~m}$ to $30,000 \mathrm{~m}$ (5000 m (purple circle), $10,000 \mathrm{~m}$ (thick green cross), 12,000 $\mathrm{m}$ (purple cross), 15,000 m (pink cross), 20,000 $\mathrm{m}$ (red cross), 25,000 $\mathrm{m}$ (oxblood triangle), 30,000 m (light brown triangle))

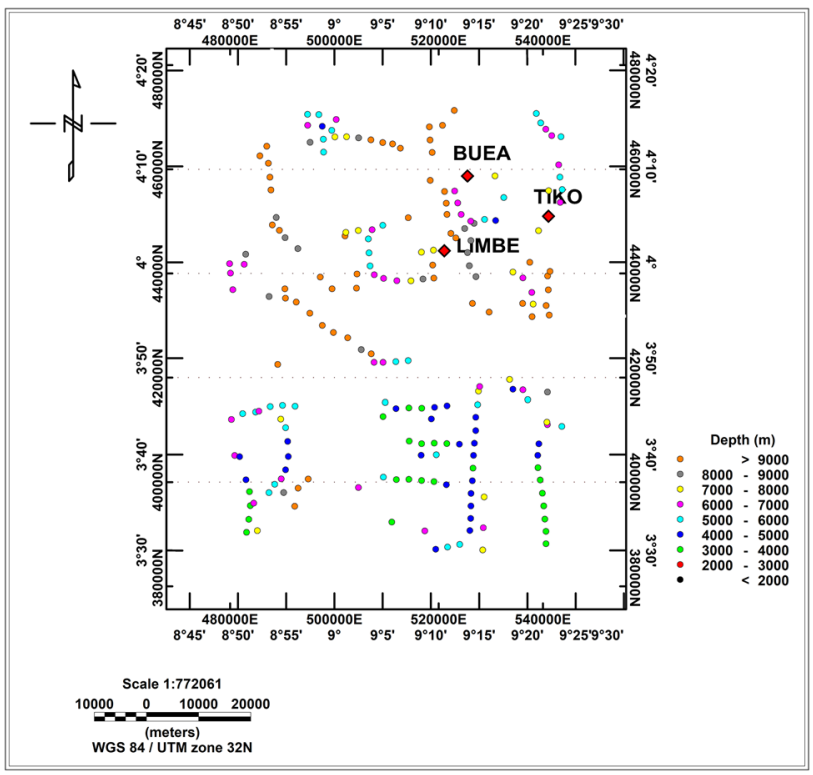

Fig. 17 Depth solutions for HGM with assumed source type as vertical density contacts

depths approximately greater than $4 \mathrm{~km}$, the quasi-circular outlines of the intrusive body which had been identified in this study area. This body has been shown to stretch

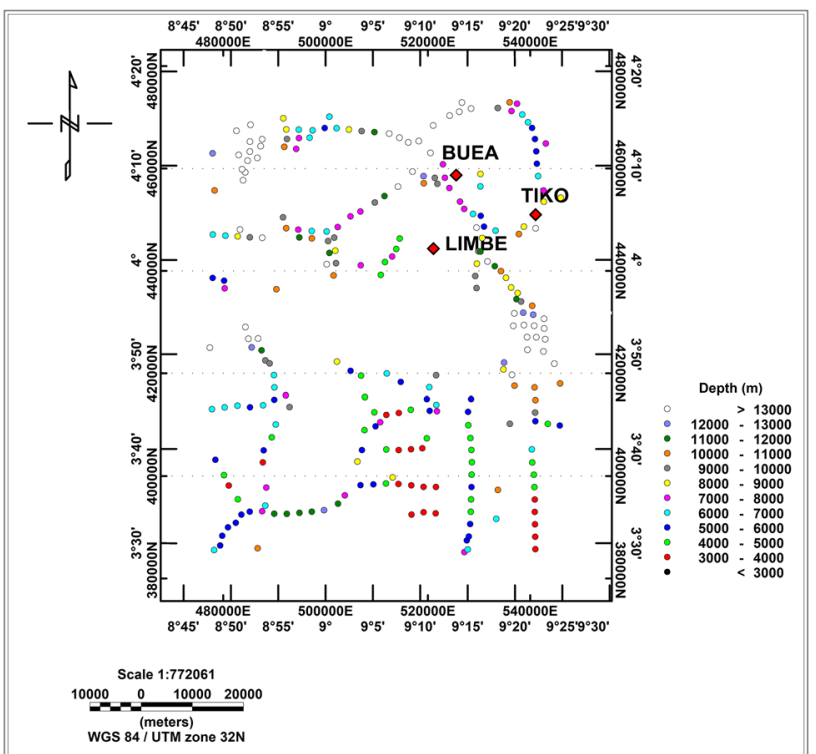

Fig. 18 Depth solutions for HGM with assumed source type as horizontal density sheets

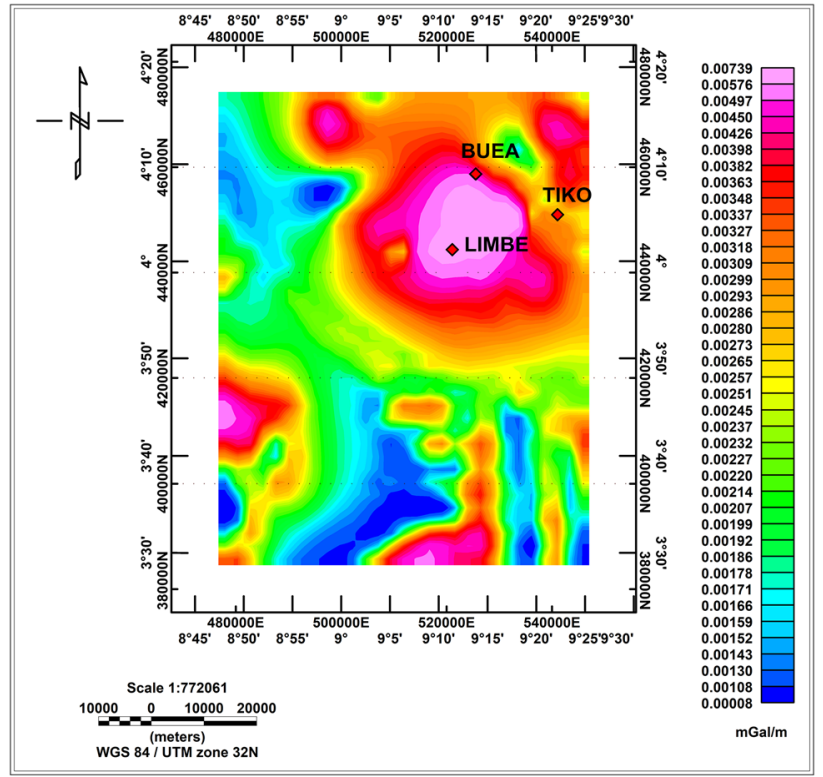

Fig. 19 Analytic signal map of study area

beyond this study area toward the south. For depths approximately less than $4 \mathrm{~km}$, both Euler 3D deconvolution and SED solutions indicated the presence of many geological contacts, though their nature and orientations were not clearly identifiable.

Special function analysis through the multi-scale horizontal derivative (MSHD) and depth solutions of the horizontal gradient magnitude (HGM), the analytic signal (AS) and the local wavenumber (LW) were able to 


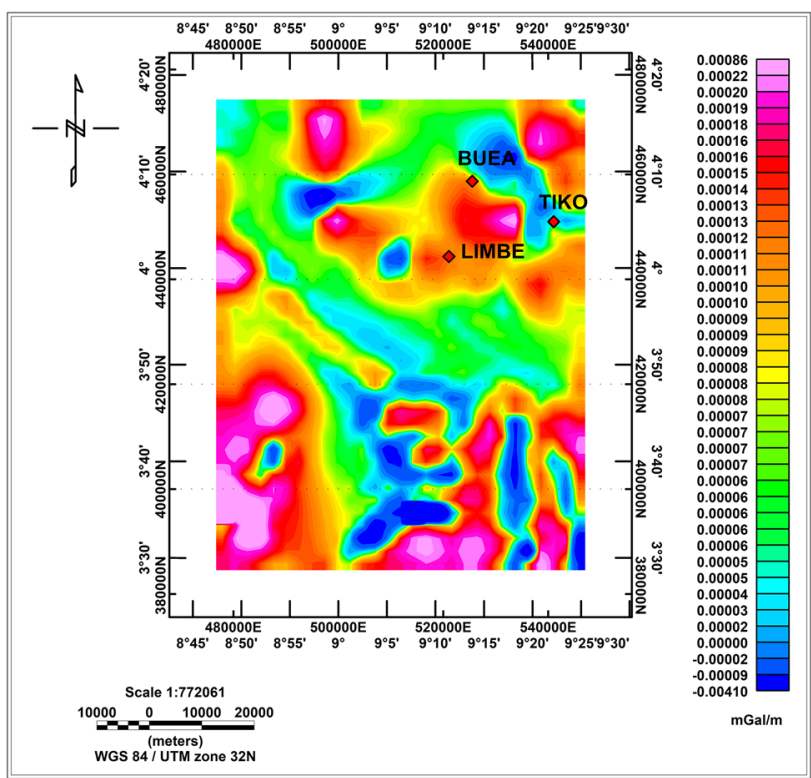

Fig. 20 Local wavenumber map of study area

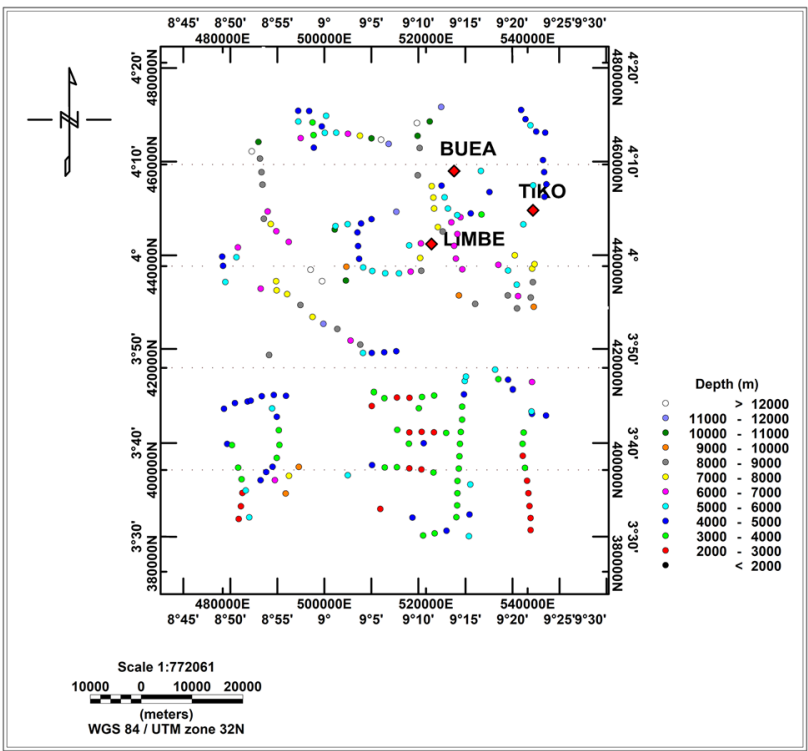

Fig. 21 Depth solution of analytic signal

better characterize the highlighted geological contacts for depths less than $4 \mathrm{~km}$. Some major faults with N-S, NE-SW, NW-SE and E-W orientations as well as minor faults with NW-SE, E-W and NE-SW orientations were identified, with dip directions generally pointing away from the center of the study area. From the depth solutions, the faults and contacts in this area of study were shown to be buried at a minimum depth of about $2 \mathrm{~km}$ with the majority of them having a structural index value in the range -0.8 to 0 .

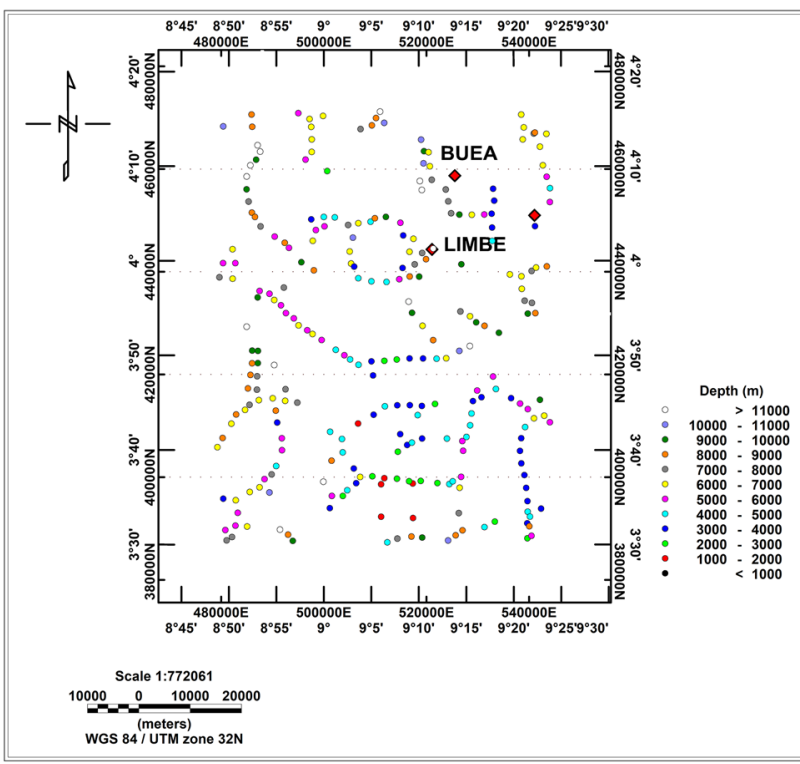

Fig. 22 Depth solution of local wavenumber

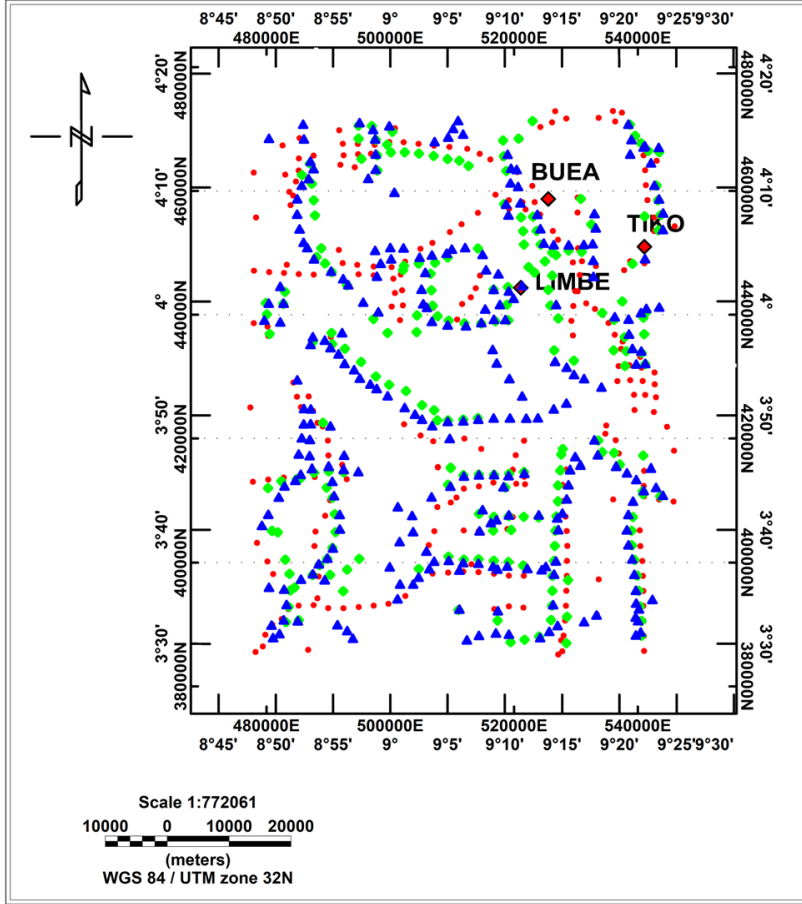

Fig. 23 Superimposition of depth solutions of the analytic signal, the local wavenumber and the HGM

It is important to note that these results will be enriched if more field data could be obtained and introduced into the studies. 


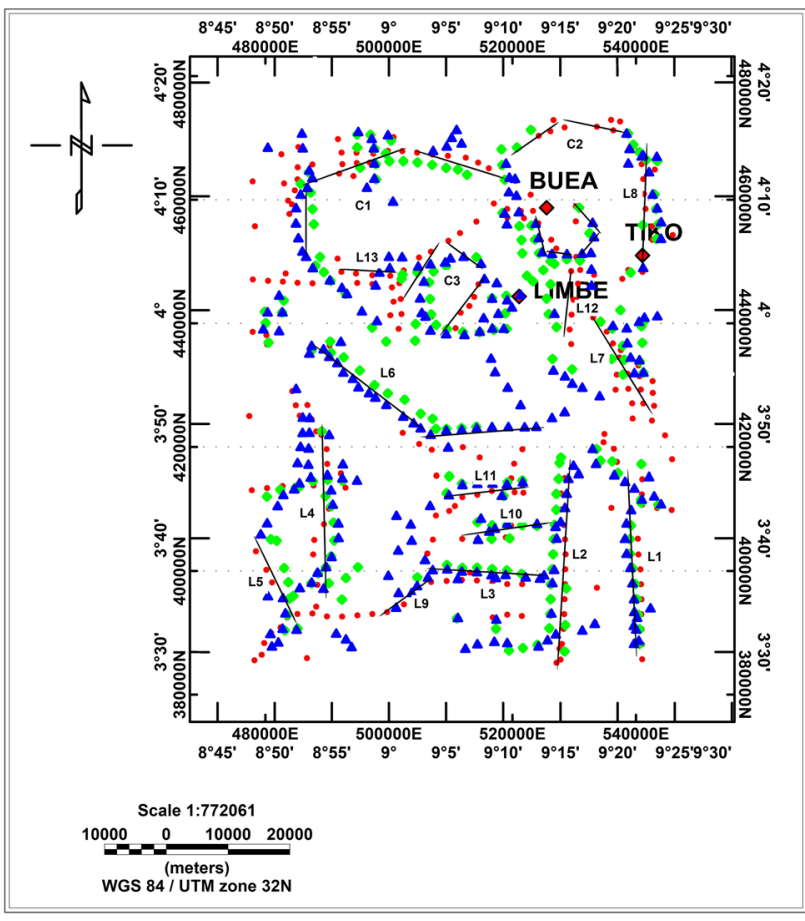

Fig. 24 Structural map of study area showing major and minor faults

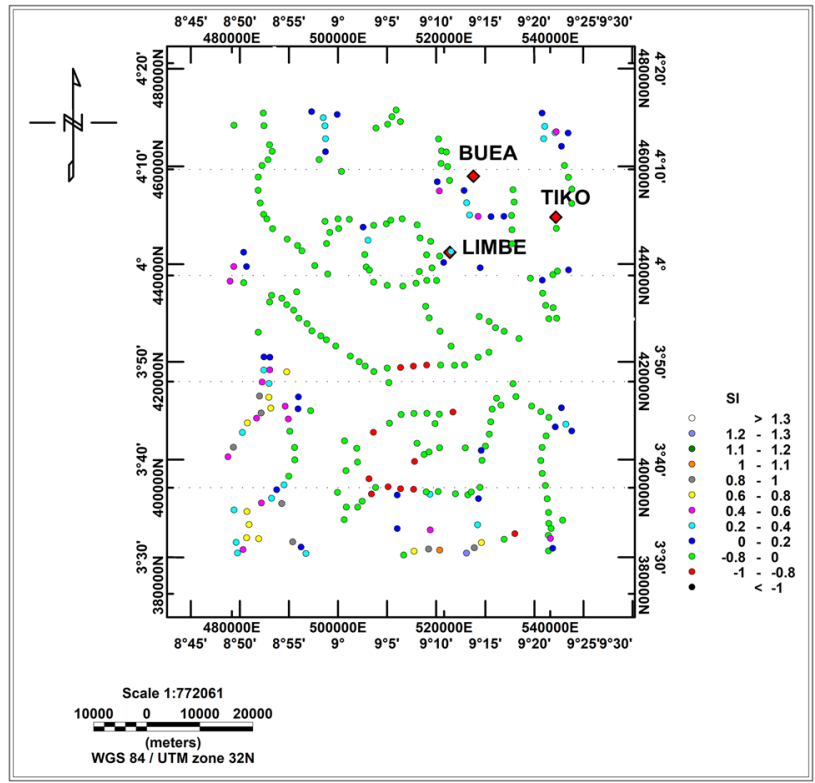

Fig. 25 Structural index plot from local wavenumber

Acknowledgement The authors greatly appreciate the insightful contributions from anonymous reviewers.

\section{Compliance with ethical standards}

Conflict of interest On behalf of all authors, the corresponding author states that there is no conflict of interest.

\section{References}

1. Tadjou JM, Nouayou R, Kamguia J, Kande HL, Manguelle-Dicoum E (2009) Gravity analysis of the boundary between the Congo Craton and the Pan-African Belt of Cameroon. Austrian J Earth Sci 102:71-79

2. Owona Angue MLC, Tabod CT, Nguiya S, Kenfack JV, Tokam Kamga AP (2013) Delineation of lineaments in South Cameroon (Central Africa) using gravity data. Open J Geol 3:331-339. https ://doi.org/10.4236/ojg.2013.35038

3. Owona Angue MLC, Nguiya S, Nouayou R, Tokam Kamga AP, Manguelle-Dicoum E (2011) Geophysical investigation of the transition zone between the congo craton and the Kribi-Campo sedimentary basin (South-West Cameroon). South Afr J Geol 114:145-158. https://doi.org/10.2113/gssajg.114.2.145

4. Owona Angue MLC, Assembe SP, Njingti N, Ngoh JD, NdougsaMbarga T, Kue Petou RM, Bisso D (2016) Determination of the structural lineaments in the Kribi-Campo-Ma'an area from a multi-scale analysis of gravity data using the HGM and Euler 3D deconvolution approaches. Int J Geosci 7:1122-1143. https:// doi.org/10.4236/ijg.2016.79085

5. Manguelle-Dicoum E, Bokosah AS, Kwende-Mbanwi TE (1992) Geophysical evidence for a major Precambrian schist-granite boundary in Southern Cameroon. Tectonophysics 205:437-446. https://doi.org/10.1016/0040-1951(92)90447-E

6. Ngoumou PC, Ndougsa Mbarga T, Assembe SP, Kofane TC (2014) Evidence of iron mineralization channels in the Messondo area (Centre Cameroon) using geoelectrical (DC \& IP) methods: a case study. Int J Geosci 5:346-361. https://doi.org/10.4236/ ijg.2014.53034

7. Koumetio F, Njomo D, Tabod CT, Noutchogwe TC, Manguelle-Dicoum E (2012) Structural interpretation of gravity anomalies from the Kribi-Edea zone, South Cameroon: a case study. J Geophys Eng 9:664-673. https://doi. org/10.1088/1742-2132/9/6/664

8. Koumetio F, Njomo D, Tatchum CN, Tokam KAP, Tabod CT, Manguelle- Dicoum E (2014) Interpretation of gravity anomalies by multi-scale evaluation of maxima of gradients and 3D modelling in Bipindi Region (South-West Cameroon). Int J Geosci 5:14151425. https://doi.org/10.4236/ijg.2014.512115

9. Malquaire KPR, Louise OAM, Nfor N, Eliezer M-D (2017) 3D modelling from new and existing gravity data of an intrusive body in the northern part of Kribi-Campo sub-basin in Cameroon. Int J Geosci 8:984-1003. https://doi.org/10.4236/ijg.2017.88056

10. Manguelle-Dicoum E (1988) Etude Geophysique des structures superficielles et profondes de la region de Mbalmayo. [Geophysical study of the superficial and deep structures of the Mbalmayo Region]. Ph.D. thesis, Universite de Yaounde I, Yaounde, $202 \mathrm{pp}$

11. Shandini Y, Tadjou JM (2012) Interpreting gravity anomalies in South Cameroon, Central Africa. Earth Sci Res J 16:5-9

12. Manguelle-Dicoum E, Nouayou R, Bokosah AS, Kwende-Mbanwi TE (1993) Audio magnetotelluric soundings on the basementsedimentary transition zone around the eastern margin of the Douala basin in Cameroon. J Afr Earth Sci 17(4):487-496

13. Ndikum EN, Tabod CT, Essimbi BZ, Koumetio F, Noutchogwe CT (2014) Gravity model for an anomalous body located in the NW portion of the Douala sedimentary sub-basin, Cameroon (Central Africa). Open J Geol 4:524-541. https://doi.org/10.4236/ ojg.2014.410039

14. Ndikum EN, Tabod CT, Koumetio F, Tatchum NC, Victor KJ (2017) Evidence of some major structures underlying the Douala sedimentary sub-basin: West African Coastal Basin. J Geosci Environ Prot 5:161-172. https://doi.org/10.4236/gep.2017.57013 
15. Nzeuga AR, Nouayou R, Njandjock PN, Fairhead JD (2017) Geophysical features of Douala sedimentary basin inferred from the analysis of aeromagnetic data. Int J Eng Res Appl 7(11):34-41. https://doi.org/10.9790/9622-0711033441

16. Kenfack PL, Ngaha PRN, Ekodeck GE, Ngueutchoua G (2012) Mineralogic characterization and petroleum potential of clays (shales) of the N'Kapa formation (paleocene-eocene) in the Douala sedimentary sub-basin (South-West Cameroon). Int J Geosci 3:696-709. https://doi.org/10.4236/ijg.2012.34070

17. Kenfack PL, Njike PRN, Ekodeck GE, Ngueutchoua G (2012) Fossils dinoflagellates from the northern border of the Douala sedimentary sub-basin (South-West Cameroon): age assessment and paleoecological interpretations. Geosciences 2:117-124. https://doi.org/10.5923/j.geo.20120205.03

18. Pauken RJ (1992) Sanaga Sud field, offshore Cameroon, West Africa. In: Halbouty MT (ed) Giant oil and gas fields of the decade 1978-1988. American Association of Petroleum Geologists Memoir, Tulsa, pp 217-230

19. Ngaha PRN, Belinga SME (1987) The diachronism of the basal sandstone, paleoenvironment and the role of the opening of the South Atlantic. Ann Fac Sci Earth Sci Ser IV 1(3-4):103-119

20. Dumort JC (1968) Explanatory notice of the sheet. Douala west geological recognition map at scale 1/500,000. Department of Mines and Geology, Yaounde, p 69

21. Mascle J (1976) The Gulf of Guinea (South Atlantic): a set of evolution in shear of Atlantic margins. Mem Soc Géol Fr 128:1-104

22. Guieu G, Roussel J (1984) Une interprétation des bassins côtiers ouestafricains à partir de l'histoire des dépôts salifères dans le cadre de l'ouverture de I'Atlantique. Bull Soc Géol Fr 6(7):1149-1164

23. Séguret $M$ (1988) Evolution de la marge passive type Afrique de I'Ouest. Mem Centre de rech Explor-Prod Elf Aquitaine 7:631

24. Hedberg JD (1969) A geological analysis of the Cameroon trend. Ph.D. thesis, dissertation, Princeton University, Princeton

25. Delteil JR, Le Fournier J, Micholet J (1975) Schéma d'évolution sédimentaire d'une marge continentale stable: Exemple type du golfe de Guinée, de l'Angola au Cameroun. IXè Congrès International de Sédimentologie. Thème 4:91-97

26. Brownfield ME, Charpentier RR (2006) Geology and total petroleum systems of the west-central coastal province (7203), west Africa. U.S. Geological Survey Bulletin 2207-B. http://www.usgs. gov/bul/2207/B/

27. Benkhelil J, Giresse P, Poumot C, Ngueutchoua G (2002) Lithostratigraphic, geophysical and morpho-tectonic studies of the South Cameroon shelf. Mar Petrol Geol 19:499-517

28. Manga CS (2008) Stratigraphy, structure and prospectivity of the southern onshore Douala Basin, Cameroon, Central Africa. Afr Geosci Rev 1:13-37

29. Ngon GFN, Etame J, Ntamak-Nida MJ, Mbog MB, Mpondo AMM, Martine G, Yongue-Fouateu R, Bilong P (2012) Geological study of sedimentary clayey materials of the Bomkoul area in the Douala region (Douala sub-basin, Cameroon) for the ceramic industry. C R Geosci 344:366-376. https://doi.org/10.1016/j. crte.2012.05.004

30. Nguene FR, Tamfu S, Loule JP, Ngassa C (1991) Paleoenvironnements of the Douala and Kribi/Campo subbasins in Cameroon, West African. Géol Afr 6-8:129-139

31. Regnoult JM (1986) Synthèse gélogique du Cameroun. D.M.G., Yaoundé

32. SNH/UD (2005) Stratigraphie séquentielle et tectonique des dépôts mésozoïques syn-rifts du bassin de Kribi/Campo. Rapport non publié, $134 \mathrm{pp}$

33. Takodjou Wambo JD, Ganno S, Afahnwie NA, Nomo NE, Mvondo OJ, Nzenti JP (2016) Use of landsat $7 \mathrm{ETM}^{+}$data for the geological structure interpretation: case study of the NgouraColomines area, Eastern Cameroon. J Geosci Geomat 4(3):61-72. https://doi.org/10.12691/jgg-4-3-3

34. Collignon F (1968) Gravimetrie et reconnaissance de la Republique Federale du Cameroun. [Gravimetry and recognition of the Federal Republic of Cameroon]. ORSTOM, Paris, 35 pp

35. Louis $P(1970)$ Contribution Géophysique à la Connaissance Géologique du Bassin du lac Chad. ORSTOM, Paris

36. Albouy Y, Godivier R (1981) Cartes Gravimétriques de le République Centrafricaine. ORSTOM, Paris

37. Okereke C (1984) A gravity study of the lithospheric structure beneath west Africa rift system in Nigeria and Cameroon. Ph.D. Thesis, University of Leeds, Leeds

38. Poudjom DYH, Nnange JM, Diament M, Ebinger CJ, Fairhead JD (1995) Effective elastic thickness and crustal thickness variation in West Central Africa inferred from gravity data. J Geophys Res 100(B11):22047-22070. https://doi.org/10.1029/95JB01149

39. Tadjou JM, Manguelle-Dicoum E, Nguiya S, Kamguia J (2008) Caractéristiques des Anomalies Gravimétriques du Sous-Bassin Sédimentaire de Kribi-Campo (Sud-Cameroun). Afr Geosci Rev $1-2: 39-50$

40. Crenn, Y. (1957) Measure Gravimétriques et magnétiques dans la partie central de I'A.O.F. Interpretation géologique. Publi. série géophys. ORSTOM, Paris, $43 \mathrm{pp}$

41. Whitehead N, Musselman C (2005) Montaj Grav/Mag interpretation, tutorial and user guide. Geosoft Inc, Toronto, pp 1-77. www.geosoft.com

42. Reid AB, Allsop JM, Granser H, Millet AJ, Somerton IW (1990) Magnetic interpretation in three dimensions using Euler deconvolution. Geophysics 55:80-91

43. Thompson DT (1982) EULDPH: a new technique for making computer-assisted depth estimates from magnetic data. Geophysics 47:31-37

44. Blakely RJ, Simpson RW (1986) Approximating edges of source bodies from magnetic or gravity anomalies. Geophysics 51:1494-1498

45. Philipps JD, Hansen RO, Blakely RJ (2007) The use of curvature in potential-field interpretation. Explor Geophys 38:111-119

46. Cordell L, Grauch VJS (1985) Mapping basement magnetization zones from aeromagnetic data in the San Juan basin, New Mexico. In: Hinze WJ (ed) The utility of regional gravity and magnetic anomaly maps. Society of Exploration Geophysicists, Tulsa, pp 181-197

47. Philipps JD, Hansen RO, Blakely RJ (2006) The use of curvature in potential-field interpretation. AESC2006, Melbourne, Australia

48. Phillips JD (2000) Locating magnetic contacts: a comparison of the horizontal gradient, analytic signal, and local wavenumber methods. Soc Explor Geophys Expand Abstr 2000 Tech Program 1:402-405

49. Pilkington $M$, Keating $P$ (2004) Contact mapping from gridded magnetic data-a comparison of techniques. Explor Geophys 35:306-311

50. Thurston JB, Smith RS (1997) Automatic conversion of magnetic data to depth, dip, and susceptibility contrast using the SPI method. Geophysics 62:807-813. https://doi. org/10.1190/1.1444190

51. Archibald NJ, Gow P, Boschetti F (1999) Multiscale edge analysis of potential field data exploration. Geophysics 30:38-44

Publisher's Note Springer Nature remains neutral with regard to jurisdictional claims in published maps and institutional affiliations. 